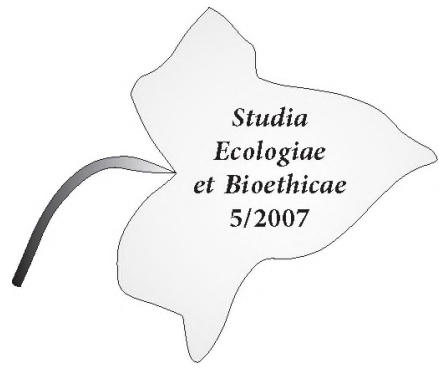

\title{
Cultural cooperation between nations as an important factor of sustainable social development of the region of Central and Eastern Europe in the European Union (for instance Poland and Lithuania)
}

\author{
Motto: So that the spirits of the dead leave us in peace... \\ (Aby duchy umarlych zostawily nas w spokoju...) \\ CZESEAW MILOSZ
}

Cultural cooperation between nations is mainly based on pacts entered by the government of the Republic of Poland and the government of the Republic of Lithuania, on cooperation between academies and cultural facilities, and on collaboration of all nations living in the given area with respect to issues important to local communities. The message of cultural cooperation is social and cultural integration.

Cultural and social co-operation among nations lived in East and Central Europe has been sprung up over many centuries. In the $20^{\text {th }}$ century, the nations of the part of Europe were subjected to an attempt to standardise their national cultures by means of introducing the socialist realist culture.

According to purposes of contemporary authorities culture was created only officially. In language of the contemporary system, social issues were taken into account mainly in the mass aspect.

The author of article is a graduate of the Institute of Librarianship and Information Science at Warsaw University and because of it in the article mainly she treats of bookseller's and publishing connected with Vilnius.

Quatation of performance of Czesław Miłosz. Günter Grass, Czesław Miłosz, Wisława Szymborska and Thomas Venclova held lectures in Vilnius on 2 October 1999. 
Polish publishers played an important role in popularising the writings of world literature published in Polish language in Poland among the other socialistic countries.

The importance of the publications in Polish is evidenced by the fact that in the former Union of Soviet Socialist Republics many outstanding works were unavailable in the Russian language or in the native mother languages of nations living at that time in the soviet republics.

Developed over the last fifteen years, relations between Poland and Lithuania constitute at the current stage of forming democratic conditions in Central and East European countries can be an example for development of cooperation among the other countries of Europe on the state and regional levels, as well as an example for stimulating citizens' initiative on the level of cooperation among cultural and educational institutions and economic associations.

The connected relations may become germs of cooperation and goodneighbourly relationship as well as in the perspective of social development of the region among the Baltic Sea, the Black Sea and the Adriatic Sea.

\section{Influence historical events and formulation of them in historiography with reference to present problems of nationality in Poland and Lithuania}

Historical conditions have impact on relations between nations to a high degree. Collecting the title honoris causa conferred by Universitatis Nicolai Copernici, professor Thomas Venclova ${ }^{1}$ said that in the Republic of Both Nations Lithuanian language was replaced by Polish language: "In eighteen century Lithuanian language was used for writing and publishing, but it was a strange speech: Polish stems, Lithuanian grammar"2. Bishop Maciej Wołączewski (Motiejus Valančius)", the author of "Samogitian Bishopiric" is reputed to be a champion of Lithuanian native revival.

Vilnius was the important center of Polish book trade and publishing enterprise at the beginning of the nineteenth century. Józef Zawadzki's firm was the representing mill of publishing order of Vilnius. The Zawadzki\&Węcki's bookshop established on $12^{\text {th }}$ August 1912 was the enterprise held in esteem in Warsaw.

Zawadzki wanted the Warsaw's branch mattered in equal degree as his firm in Vilnius. His intention was confirmed by his coming into contact with the Warsaw Society of the Friends of Sciences and undertaking publishing The Warsaw Diary. The Zawadzki\&Węcki's bookshop obtained to gain opinion of the firm which would serve scholars and society. In 1815 year the firm gave fourteen works the library of the Warsaw Society of the Friends of Sciences and promised since then to deliver one copy of each book published by their publishers. Józef 
Zawadzki supported by Stanisław Staszic and Kazimierz Kontrym drew up the statute General Rules For Booksellers' Universality in the work he proposed rules which should have been common for the universal union of people connected with a book: booksellers, printers, lithographers, bookbinders, proof-readers and printer's workers ${ }^{4}$.

In 1818 year registers of Polish books were began to publish by the company of Varsovian and Vilnian, which were published by publishers in the country and abroad. Scientists and writers used service of the firm: Feliks Bernatowicz, Julian Ursyn Niemcewicz, Stanisław Kostka Potocki, Samuel Bogumił Linde, Tomasz Święcicki, Jerzy Samuel Bandtkie.

Krystian Teofil Glücksberg was an owner of Vilnina bookshop that had essential weight of development of Vilnius as the culture publishing centre. His son Natan managed a bookshop, a publishing firm and a printing-house attached to the Wołyńskie Secondary School in Krzemieniec. In 1828 year he was appoint to a bookseller and a typographer of the Imperial Vilnian University and he established a publishing bookshop and a printing-house in the university building in Stojańska Street in Vilnius. After closure of the Vilnian University Krystian Teofil Glücksberg was appoint to the bookseller and the typographer of the Vilnian Academic Region, also the Imperial Medical Academy and the Schools of White Russian Region in Kiev. He managed many seasonal bookshops in Lithuania. He delivered many books to many country towns e.g. the first Vilnian edition poems by Adam Mickiewicz. The next individual who rendered services to the development of publishing activity in Vilnius was Maurycy Orgelbrand. He served his apprenticeship in the Zawadzki's firm, his own bookshop was established in 1853 year. In 1854 year he started making efforts to publish a new edition of Polish language dictionary. The Polish Language Dictionary For Handy Use published by Orgelbrand in 1861 year was a great improvement with reference to the dictionary edited by Linde. The dictionary was published before the January Uprising, known as "Vilnian" ("Wileński"), representatives of academic region were going to distribute to all school librarians. At the same time when "The Dictionary" was published, Polish language was lectured in public schools in Lithuania and a new university was to embark on its enterprising in Vilnius. After overthrow of the January Uprising czar's general Michail N. Murawjow, known as "Vieshatiel" , on the ground of circular from $18^{\text {th }}$ January 1864 year, forbade to teach Polish language and to use Polish handbooks, and on the ground the decree from 1865 year The Dictionary published by Samuel Orgelbrand was forbidden in the "North-West country" 5.

Many Varsavian publishers graduated from the Vilnius University e.g. Walerian Krasiński, Damazy Dzierożyński.

B After overthrow of Polish January Uprising he ordered Polish insurgents to be hung. 
In delivered lecture in Vilnius in October 1999 year Czesław Miłosz confirmed that before the Second World War inhabitants broke up into Polish district and Jewish district of Vilnius. In point of fact there were two distinct cultural towns, which existed side by side, almost were not communication mutually. At that time Lithuanian people made a minute part of people lived in Vilnius 6 . Writers belonged to literary groups did not resign themselves to divisions. Polish poets from "Zagary" group held friendly intercourse with poets whom wrote in Yiddish language and were assembled in the "Jung Wilne" group 7 . In Jewish district of the town commonly Yiddish language dominated. In Vilnius there were published books, literary periodicals in Yiddish language and Hebraic language, theatres took pride in rich repertoir ${ }^{8}$.

In 1939 year it was the first immediate contact Polish writers and journalists with Lithuanian brother-writers in Kaunas connected by Konrada Górskiego, Stanisława Ryszarda Dobrowolskiego, Karola Irzykowskiego. In that time linked relations were maintained during the Second World War.

Poland and Lithuania were at war since 1920 to 1938 year $^{9}$. In that period Vilnius was under the Polish government. On $17^{\text {th }}$ September 1939 year after crossing Poland's border by the Red Army soviet soldiers began invading Vilnius and the region near by Vilnius, afterwards the soviet invader handed the grounds over to Lithuania. It protected Poles lived in Lithuania from transportation to Siberia. That year the Stefan Batory University was closed on the ground the decree of Lithuanian Civil Service from one day to the next.

During the Second World War Polish and Lithuanian literary partnership surpassed publishing matters. Lithuanian distinguished poet Liudas Gira wrote beautiful poems: To Future Poland, Today Fighting Poland (1941), In Honour of You, Soldier (1943) and a poem Adomas Mickevičius Pavolgyje. In the poems written in Polish language the author represented his opinion of relationship between nations. Since "autumn tide of nations" historians from Central and Eastern European countries have been meeting in order to work out the common attitudes to dramatic occurrences in which their nations participated in the twentieth century.

In 2002 year the Polish Institute National Commemoration (Instytut Pamięci Narodowej) and Lietuvos Gyventojų Genocido ir Rezistencijos Tyrimo Centras negotiated the treaty, which vertified their cooperation. Scientists raise essential problems concerning the last history of the both countries for discussion. The Polish Institute National Commemoration plans series meetings with Lithuanian historians, the purpose of dissusions will be settlement common standpoint to Polish and Lithuanian partnership in the period from 1939-1989. In 2003 year it was held the second scientific conference Defiance movement of society repression system in Poland and Lithuania 1944-1956, Polish and Lithuanian partnership 1939-1989. Apart from Polish and Lithuanian historians, representatives of 
Lithuanian scientific and combatants of the both sides partisans of the Red Army and Lithuanian took part in the discussion ${ }^{10}$. Polish, Lithuanian, Ukrainian and White Russian historians negotiated common version of historic events, which took place in the Polish-Lithuanian-White Russian border-line, and all nations were parties to a suit.

Historians from the mentioned above countries treat of nationalistic problems in the formulation of historiography of their countries in Białystok in 2002 year Universitatis Nicolai Copernici in Torun in 2005 year $^{11}$.

Lithuania. History of State and Nation by Henryk Wisner ${ }^{12}$ was Polish scientific historical book, inserted in sources of the other countries of the region (Bielaruski Historycny Ahlad).

Cause of many Polish and Lithuanian conflicts was that, Lithuanian people considered German Nazi invaders to be their defenders against the Soviet Russia. Lithuanians, who joined the Security Force Sauguma subordinated Gestapo, perpetrated crimes against Poles. The Home Army in 1944 defeated Lithuanian forces Lietuvos vietine rinktine under command of general Povilas Plechavieius. Because of two policemen whom collaborating to German Nazis were killed by soliders of the Home Army ${ }^{13}$, the Red Army shooted down thirty eight Poles in Glinciszki in June 1944 year. Answer of the Home Army was an attack upon Dubinki under Zygmunt Szendzielarz's „,tupaszka” command, when twenty seven inhabitants of Dubinki were murdered, also Poles. Women and children were victims of both sides. Sixty years later in 2004 year represents of the Polish government and the Lithuanian government set their name to the declaration of reconciliation in the interest of the Club Veterans of the Home Army and of the Lithuanian Subsidiary Corps. Registration of the original name of the Club of Veteran of the Home Army in Lithuania. During the planned scientific conferences historians from Poland, Lithuania, Germany will meet in order to explain historical occurrence. In the declaration it was ascertain that after reconciling Germans with Frenchs and Poles there came a time when Poles and Lithuanians antagonists of the last war became reconciled.

Immediately after the Second World War the communist authorities made about two hundreds thousands Poles leave Lithuania, more or less those people were from Vilnius. At the same time contemporary authorities objected to mass leaving of country-people, because executive power wanted to keep menpower in a country. Polish people were deprived of Polish intelligentsia. Lots of repatriates, whom could not stand on their feet again in the arised situation, because of "neither we are from Vilnius nor Poles", were described in the scientific book Children of Jalta. Exodus of Poles from Vilnius region in the period 1944-1947 by Alicja Paczoska, a historian working in the Polish Institute National Commemoration. The book was published publishers, which has been specialized in publications about Vilnius. 
In spite of fixes in the period of real socialism Polish press played the important cultural role in Lithuania and in other republics of the Soviet Union. Polish language was needed for Lithuanians, who wanted to read works of world literature approachable in Polish bookshops in their country. It was confirmed by Lithuanian poet Thomas Venclova: "In 1965 year I was nineteen years old. Polish newspapers approachable in each kiosk in Vilnius were immensely interesting for a man living in the Soviet Union. Readers could find out a lot of about cultures in the world and also about policy. Because of that I decided to learn Polish. There was the Polish bookshop in Vilnius. Books written by Miłosz or Gombrowicz were not in it, but there were, inaccessible in Russian or Lithuanian language, Polish translations of the work of world literature. In the Polish bookshop I bought Golema written by Meyrika and For Whom the Bell Tolls written by Hemigway ${ }^{14}$.

Articles, in which there are treated of scientific attainments by historians and social politicians from Central and Eastern Europe, are published in scientific periodicals e.g. Lithuanian Historical Studies, Lituano-Slavica Poznaniensia. Studia Historica, Eastern Review, Bielaruski Historycny Ahlad, Slavonic Memoris and in a quarterly Lithuania. The first number of the quarterly published in February 1990 year was handled the fight of Lithuanians for independence in the next numbers staff members of Lithuania decided to publish articles of scientists, whom represented their standpoint to matters important for both countries. At suggestion of professor Jerzy Kłoczowski the Institute of Central and Eastern Europe was created. As circumstance of creation of the Institute its initiators indicated necessary of revelation of cultural and social specificity of Central and Eastern Europe as the region spreading over an area among the Baltic Sea, the Adriatic Sea, the Black Sea. In the ICEE the following research programmes are carried on: "The present situation social and cultural Central and Eastern Europe" (a research project) ${ }^{15}$, "History of White Russian Lithuania, Poland and Ukraine in the new historiographic formulation" (a research and publishing project), "History of Central and Eastern Europe" (also a research and publishing project), "Processes of integration, traditions of tolerance and culture of peace in history of Central and Eastern Europe". In researches carried in framework of the last project it was pointed at historic tradition, at the same time scientist were engaged on designation of the present aspect of tolerance in the context of dynamic revaluations and changes what have been occurring in the societies of Central and Eastern Europe. Conclusions were published in the book "Identity and dissimilarity, tolerance and culture of peace", brought out in Lublin in 1999 year $^{16}$. It is important to keep bonds among people connected during important events which joined them. The Union of Lithuanian in Poland celebrated an anniversary near by the Monument Lithuanian Airmen which took place in Myślibórz not far from Szczecin on $18^{\text {th }}$ July 2004 year. 
It was realized the research and publishing project "Archival sources to history of Church in the Republic (of Poland and Lithuania) and in Russia since the end of $18^{\text {th }}$ to $20^{\text {th }}$ century. The result of works of the team of research workers was published as a form of some volumes of materials and archival inventories, which particularly concerned history of the Catolic Church in the $19^{\text {th }}$ century. The problems connected with the region were under discussion during conferences organized by the ICEE, e.g. "Confines and transformations national space in history of Central and Eastern Europe. Example of White Russian, Lithuania, Poland and Ukraine" which occurred in Dąbrowice in 1998 year".

Czesław Miłosz said: "profession of historian just consists in this, he must believe in the possibility of attainment of objective truth different than the myths, which gathered on facts and a historian seeks access to truth to grub in archives".

Undertaken activities are to renew historically shaped bonds between the Lithuanian nation and the Polish nation. The affirmativing examples can be Polish and Lithuanian conference The Constitution of May 3 and the present time, what took place in Vilnius in 1991 year.

Standpoint of historians surroundings intensely influences public opinion and relations of members of national minorities. Opinions of historiorians serve elimination reasons of potential conflict, e.g. the Lithuanian school historical atlas in which the period from 1920-1939 was defined as "Polish occupation the region of Vilnius and the region of Suwałki" ${ }^{17}$.

The consequence of represented above historic events is a weaker level of the education of Poles, most of them live in countries. In the former the Russian Soviet Federative Socialist Republic people who educated in secondary schools and universities, had to study in Russian language. At the beginning of the transformation of political system in White Russia and Ukraine about thirty per cents people, who had Polish descent, considered Russian language their mother language. Lithuania was the soviet republic where in the communist period, Polish educational system performed and eighty five per cents Poles presented Polish as their mother language (in 1989 year).

Young Poles descend from those regions, educated in Polish schools, either stayed in Poland or chose one of Western European countries of destination, if they returned to Lithuania, serious difficulty was lack of contacts to receive a job suited to their qualification and unacquaintance with Lithuanian language, which was the national language ${ }^{18}$. As things are it is possible to maintenance of Polish culture only as culture of national minority.

Polish youth organizations in Lithuania perform important social functions. One of the first cultural Polish activity was creation of opened sport club of Poles "Polonia". Professor Janusz Jaszczanin became the chairman of the Kaunas Institute of Physical Culture ${ }^{19}$. 
In the field of help and cultural cooperation with Poles living in the East the resolution of the Polish government, in which there is separated $5^{\text {th }}$ point in addition dedicated to "Help surroundings Poles in the East". In the document it was foundation of realization of the cultural works: help them with compliance with religious and moral requirements, preservation of monument of Polish culture, turning Polish magazines and newspapers over to Poles living in the East, making possible the reception of Polish broadcasting and television stations in countries close by Poland, the initiation of cyclical broadcasts. Development of Polish culture in Lithuania is considered to be model for future works, which the Polish government may undertake and address to Poles living in White Russia and Ukraine. Cultural interchange should be bilateral, because Poles living in the East are co-originators of Polish national culture. The Senat of the Polish Republic is the organ undertook to solicitude be solicitous for Poles living abroad.

\section{Situation of Polish minority at the beginning of the political transformations during the recovery of independence by Lithuania}

At the beginning of 1990 's before the governments signed the treaty, when people knighted for recovery of independence of Lithuania, cultural cooperation was undertaken at social suggestion ${ }^{20}$. Lithuanian people gave utterance to initiative in relation to Polish minority yet in the communist period. On $7^{\text {th }}$ August 1989 year it was started in the Lithuanian television emission of programme "Panorama of Week" in Polish language ${ }^{21}$. In 1989 year in Vilnius it was founded the Lithuanian International Coordination Association of grouping associations and national movements Lithuanians, Russians, Poles, Hebrews (two associations) ${ }^{22}$, Tartars, Ukrainians, Armenians, Estonians and White Russian people. During the congress in Vilnius Poles created The Union of Poles in Lithuania. In 1990 year in Lithuania, hitherto the nation had been religiously indifferent, it was created the Catolic Association of Poles in Lithuania ${ }^{23}$.

The Club of Polish Culture in Vilnius began its activity in February 2001 year. It is a place for people who represent varied levels of education, political opinions, social circumstances. There are abodes of Polish social associations in the building. Culture works of the Club of Polish Culture in Vilnius comprise: monthly varnishing-day of new painting, graphic art, photographic, kids output, exhibitions, book introduction, poetic evenings, meetings with Polish poets, writers from Poland and Lithuania, concerts, performances, competitions e.g. Polish songs, conferences, courses of instruction ${ }^{24}$. Polish Book Fairs also take place in the Club of Polish Culture. The J. Montwiłła Foundation of Polish Culture in Lithuania made an endowment of commemorating plate in Lithuanian and Polish languages ${ }^{25}$. 


\section{Cooperation among universities induced social initiative to development of cultural activity and to connect ties}

Academies began cooperation independent of political situation. Faculty of Arts of Commonwealths of Nations of Lithuania opened in the Vilnius Pedagogic Institute on $17^{\text {th }}$ October 1990 year was a proposal switched also to Polish minority.

Universitas Studiorum Polona Vilnensis was created in 1991 year $^{26}$. At the beginning USPV was active at the Association of Polish Scientists of Lithuania side, and in 1998 it received separate legal personality under the Latin name Universitas Studiorum Polona Vilnensis. The academic library own the collection of books is composed of fifty thousands of volumes, mainly Polish scientific literature, the collection also consists of old prints and documents, video set. Publishers of USPV brings out the series of the scientific periodicals Studium Vilnense $A$, the series of the books Studium Vilnense B and multimedia carriers, Studium Vilnense CD. USPV created its scientific base unaided, without allocations from the Polish government nor from the Lithuanian government. The municipality of Vilnius registered the statutes and issued a certificate of higher public convenience to Universitas Studiorum Polona Vilnensis on $18^{\text {th }}$ May 1998 year. The rectorate of USPV is going to, the university now has legal status of non-profit organization, achieve USPV to complete academic rights.

The Institute of International Relations of Universitatis Nicolai Copernici took part in the international project "Historical Bibliography 1991-2001" realized by White Russians, Lithuanians, Poles, Russians and Ukrainians. UNC pointed out the cooperation with cultural and scientific institutions in Lithuania as one of its preference works ${ }^{27}$.

Polish and Lithuanian dictionaries are available on the internet at, for example, http://www.lietpol.pl.

Number of cooperating institutions confirms development of scientific ties in spite of hard terms of transformation in Central and East European countries before the last extention of the European Union and hitherto formalities were suppressed. They are: Universitas Wratislaviensis cooperates with Vilniaus Pedagoginis Universitetas, partner academies of the Karol Adamiecki's Economic University are: the Lithuanian Law Academy in Vilnius, the Vilnius Gediminas Technical University, the University of Technology and Agriculture in Bydgoszcz cooperates with Universitas Studiorum Polona Vilnensis, the Institute of Structural Mechanics in the Faculty of Civil Engineering in the Warsaw University of Technology conluded an agreement with Vilnius Gediminas Technical University.

Cooperating university entities: Faculty of Arts of the Maria SkłodowskaCurie University (UMCS) in Lublin with Faculty of Arts University in Szawle 
Centre of History of Western Lithuania and Prussia University Klajpeda with the Institute of Submerged Archeology of Universitatis Nicolai Copernici ${ }^{28}$, the Institute of Statistics and Demography of Warsaw School of Economics with the Institute of Sociology and Demography of the Lithuanian Academy of Sciences, ISD Warsaw School of Economics cooperates with Universitas Studiorum Polona Vilnensis.

During symposia historical conditions were disused and their influence over cultural ties among nations, e.g. at the beginning of cooperation it took place the international conference "Vilnius and the region close by Vilnius as landscape and surroundings of many cultures" organized by Branch of the University of Warsaw, in 2005 year scientists met to treat of "Vilnius theatrical culture 17851914", the Polish Institute in Vilnius was the organizer of the congress. Effect of historical education on formation of opinions about contemporary relations between communities was under consideration e.g. in "Historical education and the present time. The jubilee book dedicated to professor Adam Suchoński on the occasions of the fortieth anniversary of his didactic and scientific work and of the seventieth birthday" ${ }^{29}$. In 1998 year they were lectures in the framework of VII Summer School Central and Eastern Europe at University of Vilnius. Lecturers were scientific from Poland, Lithuania, USA, France and Switzerland. In 1999 year Polish Institute inaugurated series of historical lecture ${ }^{30}$.

Rectorates of Polish universities conferred titles honoris causa on Lithuanian scientists. The Rector and the Senate of Institute of Technology in Poznań conferred titles honoris causa on professor Edmundas Zavadskas, the rector Vilnius Gediminas Technical University. Lithuanian poet Thomas Venclova conferred titles doctor honoris causa from the authorities of Universitatis Nicolai Copernici in 2005 year. Lithuanian academic surroundings valued Czeslaw Milosz to award doctor honoris causa University of Kaunas and the University of Stefan Batory (1994) ${ }^{31}$. Cooperation is led by musical and vocal groups of Academies of Music in Lodz and Klajpeda. Scientific workers of the Academy of Music in Klajpeda cooperated with the Faculty of Culture in Polega ${ }^{32}$.

University students were pushed to study abroad e.g. students from Lithuania studied in Universitatis Nicolai Copernici in Toruń.

In December 1995 year in the Librarian of the Lithuanian Academy of Science it took place the exhibition of over hundred titles of Polish scientific books, afterwards turned over to the Lithuanian institution as the present from the Polish government and Poles. In 1996 it was signed the treaty of cooperation between the Lithuanian Academy of Science and the Polish Academy of Science. On the occasions of two-hundredth anniversary of birthday of Adam Mickiewicz in 1998 year in the library of University of Vilnius were opened the exhibition of books and old prints "Adam Mickiewicz and Lithuania". 
Jan Krzysztof Broja was the first Polish participant in Mikolajus Konstantinas Čiurlionis Third International Pianistic and Organ Competitions in Vilnius. He was the first prize-winner. Professor Krzysztof Droba from the Academy of Music in Krakov taught Broja to the competitions.

In the framework of cooperation of academic students the Students' Scientific Organization in Faculty of History of Arts University of Warsaw organizes scientific camps for students who want to study cultural heritage of both countries $^{33}$. Students' Choir Collegium Musicium University of Warsaw concerts regularly in Lithuania.

In Lithuania there are groups well-disposed towards Poland, which may influence considerably e.g. the group of scientists of distinction whom impact of an invention on scientific people considerably. They need official support, which affords possibilities for permanent contacts with Poland.

Libraries are institutions supporting international cultural cooperation. Cooperation between Poland and Lithuania in the fields of culture, education and science is regulated by the agreement signed by the governments' representatives on 17 December 1999 in Vilnius ${ }^{34}$.

BOBCATSSS is a network of institutions providing education in the domain of scientific information and library science, which have been carrying out the information policy in the European Union since $1993^{35}$ year. Conferences are held regularly; they include those held in Poland (Cracow 2000 $0^{36}$, Torun $2003^{37}$ ) and in Lithuania (Vilnius 2001) ${ }^{38}$. Issues important for the nations in our part of Europe were raised during the discussion in Torun, including access to information for ethnical and language minorities and problems of multilingual communities ${ }^{39}$.

International cooperation has been undertaken by university libraries, e.g. the library of Nicolas Copernicus University with the library of Vilnius University and Stefan Batory library in Vilnius ${ }^{40}$.

For the Faculty of History of Vilnius University, the library of Nicolas Copernicus University prepared part of historical documentation for the album devoted to the $425^{\text {th }}$ anniversary of Vilnius University. In 2005 the Nicolas Copernicus University Library began issuing the new series of publications entitled Sources of tradition of Nicolas Copernicus University in Torun (Źródła tradycji Uniwersytetu Mikołaja Kopernika w Toruniu, Latin title: Fontes ad historiam Universitatis Copernicanae Thoruniensis pertinentes).

The new series will include books concerning history of Vilnius University until the $19^{\text {th }}$ century. The first published title is the lectures of the eminent philosopher Piotr Marian Massonius on the history of Vilnius University, delivered in 1925 at Stefan Batory University ${ }^{41}$. Scholars from both universities and representatives of the Polish Institute in Vilnius took part in the promotion of the publication, which was carried out in the Polish and Lithuanian languages at the University Library in Vilnius. 
Readers and bibliophiles might visit the ex libris exhibition of the Lithuanian graphic artist, professor of the Faculty of Arts of Siauliai University, Vaidotas Janulis, organised at the Maria Curie-Skłodowska University Museum in 2004. Bibliographies are certainly a source which reflects cultural achievements. The Lithuanian National Bibliography is available in the Internet at www.lnb.lt.

Bibliography of Eastern Europe (Poland-Lithuania-Belarus-Ukraine-Russia) lists academic publications which came out in those countries, playing a very important role to science because of limited scientific exchange between the countries of this region. It is published in volumes devoted to particular countries, prepared by the teams in Warsaw, Vilnius, Minsk, Moscow and Lvov. Among others, the following volumes have been published: Polish Bibliography 1993 v. 2, Polish Bibliography 1994 v. 4, Polish Bibliography 1995 v. 7, Bibliography of Polish research on nations and religion v. 9, Lithuanian bibliography 1991-1994 v. 3 and Lithuanian bibliography 1995-1996 v. 8. In Poland the work is performed by Warsaw University's Chamber of East European Studies.

The editorial team of Lithuania ${ }^{42}$ declared in 1990 its intention to compile a professional press bibliography of specialists in Lithuania-related issues and books concerning Lithuania.

At the beginning of transformation in Lithuania, the Polish social magazines which most often undertook Lithuania-related topics were: Więźz ${ }^{43}$, Tygodnik Powszechny (by Martinaitis Marcelijus, Triptych I, Triptych II, Triptych III) ${ }^{44}$, Kresy (a poem Forest celebrations by Kazys Bradunas) ${ }^{45}$ and Wiadomości Uniwersyteckie (a poem Ghetto by Tomas Venclova) ${ }^{46}$.

Fans of literature were able to acquaint themselves with Lithuanian literature and critics' opinions in Literatura ${ }^{47}$, Czas Kultury ${ }^{48}$, Literatura Radziecka ${ }^{49}$, Teksty Drugie ${ }^{50}$, Znad Wiliti ${ }^{51}$ and Zeszyty Literackie ${ }^{52}$. Articles concerning social and cultural matters appeared in Lithuania (issue 3/4 of 1997 was devoted to discussing similarities and differences between Polish and Lithuanian cultures) $)^{53}$ and Europa Orientalis ${ }^{54}$. Works of Lithuanian writers were also published in Przeglad Polski $i^{55}$, Po Prostu ${ }^{56}$, Odra ${ }^{57}$, Nowa Fantastyka $a^{58}$, Pieśn Skrzydlata ${ }^{59}$, Studia i Materialy Tytu $\}^{61}$, Gazeta i Nowoczesnośćc ${ }^{62}$, Akcent $t^{63}$, Przeglad Kresowy ${ }^{64}$, Kurier Wileński $i^{65}$, Magazyn Wilenski ${ }^{66}$ and Czerwony Sztandar ${ }^{67}$.

Polish Literary Bibliography (Polska Bibliografia Literacka) available on the internet is a listing of publications, compiled for specialists in Lithuanian issues and those interested in contemporary Lithuanian literature. It contains among others studies (e.g. In the circle of Lithuanian Literature issued in 1991), articles on Polish-Lithuanian contacts (e.g. quasi-literary texts by Czesław Miłosz Conversation concerning Lithuania ${ }^{68}$ and by Tomas Venclova Open letter to Lithuanians and Poles in Lithuania ${ }^{69}$ ), texts about events, cultural issues, collections of poems (Venclova Tomas Six poems 1991), prose (e.g. Stories by Jonas Biliunas 1990). Articles in which scholars discuss Lithuanian literature or 
literature connected with Lithuania, were published among others in Litteraria $^{70}$ and Kresy i Pogranicza ${ }^{71}$.

Within the "Closer to Poland" programme, the Adam Mickiewicz Institute dealt with distribution of Polish magazines and books for persons popularising Polish culture abroad, such as Polish language teachers, translators of Polish literature, Polish studies specialists, Slavonic studies specialists, literary scholars, journalists, columnists and organisers of cultural life. Polish publications are delivered to libraries, universities, to faculties of Polish and Slavonic studies, as well as to cultural, academic and governmental institutions. Twenty Lithuanian printing houses presented books in 1995 at the $40^{\text {th }}$ International Book Fair in Warsaw. The Polish-language biweekly Form the bank of Neris (Znad Wilii) was presented at the Lithuanian stand. An exhibition of Polish Academic Book, organised by the Association of Academic Publishers under the patronage of KUL (Lublin Catholic University), UMCS (Maria Curie-Skłodowska University) from Lublin and Nicolas Copernicus University (UMK) from Torun was held in 2000 at Vilnius University.

The Adam Mickiewicz Institute in Cracow and the Polish Institute in Vilnius organised in 2003 in Vilnius the Baltic Book Fair. Books in Polish and Lithuanian, presented at the exhibition, were included into the Polish-Lithuanian publishing programme, established on the strength of resolution of the Consultation Committee of Presidents of Poland and Lithuania and the agreement between the Ministry of Culture of Lithuania and the Ministry of Culture of the Republic of Poland.

\section{Official establishment and activities undertaken within the framework of cultural cooperation between Poland and Lithuania}

Official cultural cooperation between Poland and Lithuania is carried out by institutions acting under the auspices of the Lithuanian Ministry of Culture and of the Polish Ministry of Culture. The committee for cultural heritage was established in Lithuania in 1993.

The Great Theatre from Warsaw performed in Vilnius just before the independence activities in Lithuania started. Between 31 May to 7 June 1988 it staged, among others, two operas by Stanisław Moniuszko: The Haunted Manor (Straszny dwór) and Countess (Hrabina). For the first time since forty years, the national flag of Lithuania was put up on 14 June at the Gediminas Square in Vilnius at the rally in honour of people sent on a large scale deep into the USSR. It was then that the Sajudis Lithuanian Movement for Reconstruction began forming. 
The agreement concerning cultural cooperation of Lithuania and Poland in the years 1993 and 1994 was signed in Vilnius on 21 January 1993. In 1994 a photographic exhibition, devoted to the first anniversary of signing the Lithuanian-Polish Treaty, was opened at the Lithuanian Seym. A concert of the Lithuanian State Symphonic Orchestra, under the baton of Wojciech Michniewski, took place on 26 October 1996. In 1997, at Maisons-Laffitte near Paris, Algirdas Brazauskas granted to Jerzy Giedroyc, founder and chief editor of Kultura, honorary citizenship of the Republic of Lithuania which was granted to J. Giedroyc by the President's decree for his services on the ground of Polish-Lithuanian rapprochement. In 1998 the President of Lithuania Valdas Adamkus participated in ceremonial beginning of construction of the Czesław Miłosz Cultural Centre in Szetejnie, native town of the Noble Prize winner. Creators of the centre want to arrange meetings of writers and historians and to hold artistic exhibitions. On the initiative of ambassador of the Republic of Poland, a concert of the choir of the Polish National Philharmonic Hall under the baton of Krzysztof Penderecki was organised in 1998. A Polish-Lithuanian exhibition of sculptures "Integrart '98" after an outdoor workshop was opened at the Lithuanian Seym. The Polish-Lithuanian cultural cooperation was officially confirmed by the agreement signed on 11 December 1998 between the Ministry of Culture and Art of the Republic of Poland and the Ministry of Culture of the Republic of Lithuania. The agreement was in force until 2001.

Dedicated to the $180^{\text {th }}$ anniversary of birth of Stanisław Moniuszko, a concert of classical music was held in 1999 on the occasion of celebrating the Constitution of 3 May at the Lithuanian National Philharmonic Hall. The Polish House in Vilnius was put to use in September 2000, with thirty Polish organisations acting in Vilnius and in the Vilnius region moving in there at the end of the year.

In 2001 the Polish Radio Orchestra performed concerts on 8 and 9 September at the Philharmonic Hall in Vilnius.

Global Meetings of Theatres of Polish Communities Abroad are organised in Poland. The Polish Theatre from Vilnius, which has existed for one hundred years, participated in the festival in 2003.

The Musical Theatre from Vilnius, which staged Romeo and Juliet directed by Oskaras Korsunovas, took part 2004 in the $8^{\text {th }}$ International Shakespeare Festival in the Tri-City. Within the Festival, the International Conference entitled PLAYING SHAKESPEARE TODAY - contemporary reception of Shakespeare in Baltic States organised in cooperation with the Polish Shakespeare Association took place, with Shakespeare experts from Lithuania participating.

In 2004 the Adam Mickiewicz Institute organised the Days of Polish Culture in Vilnius, which were held two and a half years after the Days of Lithuanian Culture in Poland. 
The Days of Polish Culture in Vilnius began with the Inauguration Concert at the National Philharmonic Hall in Vilnius. The symphonic orchestra of the National Philharmonic Hall in Warsaw participated in the concert, playing Concerto giocoso composed by Michał Spisak, Concerto-Cantata op. 65 for solo flute and orchestra of Henryk Mikołaj Górecki, First Violin Concerto op. 35 composed by Karol Szymanowski and a piece by Wojciech Kilar, Krzesany. The concert was broadcast by the Polish Radio and by the Lithuanian Radio. Lithuanian Television prepared a reportage presenting all the events of the Days of Polish Culture in Vilnius.

The exhibitions presented in Vilnius both referred to tradition and presented contemporary achievements of Polish artists. Before the official opening of the Days of Polish Culture in Vilnius, the public were able to visit two exhibitions: Under the white and red flag. New art from Poland the Zachęta National Gallery in Warsaw and Fashionable world. Clothes from the $18^{\text {th }}$ and $19^{\text {th }}$ centuries of the National Museum in Warsaw, opened at the National Museum in Vilnius. Cinema goers were able to participate in the cyclical event $4^{\text {th }}$ Week of the Polish Film, organised by the Polish Institute in Vilnius, which in 2004 became included into the programme of the Days of Polish Culture in Vilnius.

The exhibition Jerzy Giedroyc and the circle of "Kultura". Difficult PolishLithuanian dialogue was prepared by the Association for Custody over the Literary Institute Archives in Paris. It was presented at the Lithuanian Parliament, then moved to the Lithuanian National Library and remained in Lithuania as a touring exhibition. The authors of the exhibition Warsaw in Vilnius. Vilnius in Warsaw were artists from the Warsaw Branch of the Association of Visual Artists.

During the Days of Polish Culture, performances were staged by the Helena Modrzejewska National Old Theatre from Cracow and the Great Theatre of the National Opera House from Warsaw.

Parallel to events for broad audiences there were meetings of experts in culture, including lectures by conservators from Poland, held at the National Library, for specialists in particular fields of conservation. The Embassy of Poland presented to the National Library in Vilnius three photograms by Jerzy Gierałtowski: of Czesław Miłosz, Tadeusz Konwicki and Tomasz Niewodniczański.

In return, in March 2005 the Lithuanian National Opera House staged in Warsaw two operas: "Jewish Woman" by Frmental Halevy, directed and in the scenography of Günter Krämer, under the baton of Jonas Aleksa and "Lokis" by Bronius Kutavicius, contemporary composer familiar to the Polish audience from many performances during Warsaw Autumn. The opera "Lokis" was directed by Jonas Jurasas and conducted by Martynas Staskus. German director Günter Krämer for the first time staged "Jewish Woman" at Vienna's Staatsoper in 1999. Lithuania was represented at the $5^{\text {th }}$ Stanisław Moniuszko International Vocal Contest, which was held on 13-22 May 2004. The mandatory programme is 
considered to be very difficult, and participants have to present versatile artistic skills from opera programme to vocal lyric.

The Adam Mickiewicz Foundation for Supporting Polish-Lithuanian Cooperation operates by the offices of presidents of both countries.

On the strength of resolution dated 21 June 2002, the Senate established the Consultation Council of Polish Communities Abroad, which is a consultative body with respect to prescriptive acts concerning Poles abroad and Polish communities abroad, activities of the Senate addressed to Poles abroad and Polish communities abroad as well as in issues important to our compatriots abroad. Issues which are directly dealt with by the Council include presenting opinions concerning applications for subsidising activities of the Polish communities abroad, examination of applications for entrusting state activities with respect to custody over the Polish communities abroad and Poles abroad and analysing reports from inspection visits controlling performance of activities financed from the funds granted by the Senate.

For one year, from the middle of 2004 until 2005, Poland presided in the Council of Baltic States. The Ars Baltica cultural cooperation programme is being carried out within the framework of this cooperation. Social and cultural integration is treated as a priority of the EU Poland-Lithuania-Russian Federation (Kaliningrad Oblast) Neighbourhood Programme INTERREG IIIA CBS ${ }^{72}$.

\section{Cooperation among cultural institutions serves direct familiarisation with the cultures of other nations and social integration of people}

One of the reasons for the operation of cultural institutions is to encourage other environments and people to participate in their activities.

Cooperation of cultural institutions is regulated by the law and coordinated by the highest organs of state authorities of Poland and Lithuania on the initiative of Danuta and Leon Brodowski. In 2005 the Senate granted a subsidy with respect to entrusting the state assignment of custody over Polish communities abroad and Poles abroad to, among others, Polish Scouting Association, Polish Community Association, Polish Education Abroad Foundation, Polish Olympic Games Committee, Common Knowledge Educational Society, Global Association of the Polish National Army Soldiers in Warsaw.

A Lithuanian artist closely connected with Poland was Mikolajus Konstantinas Ciurlionis. On the initiative of Warsaw Lithuanians, in 1970 s a commemorative tablet in honour of Čiurlionis was placed at 45 Zurawia Street. The M.K. Ciurlionis Educational and Cultural Association has cooperated for years now with Adelbertas Nedzelskis from Druskininkai, who in 1963 established the 
Čiurlionis Museum. In 1995 the Embassy of Lithuania in Poland arranged a ceremonial concert to commemorate the $120^{\text {th }}$ anniversary of birth of M.K. Čiurlionis. An exhibition of Čiurlionis' reproduction was opened in July 1995 at the Historical Museum of the Capital City of Warsaw.

The Festival of Polish Culture "Polish flowers" is traditionally held in Lithuania each year.

The Lithuanian Friendship Club of Poland was established in 1989. Since 1990 the Club has been publishing the Lithuania quarterly, and then the Lithuania's Library publishing series. Moreover, the Club has organised international conferences, with scholars, creators of culture, members of parliament and politicians of both sides, youth, social activists and experts in issues important for the Polish and Lithuanian sides as well as for other countries of Central and Eastern Europe presenting their opinions there. At the meetings organised by the Club opinions were presented by, among others, members of the Association of Polish Lithuanians, Lithuanian diplomats, e.g. Rimantas Stankevičius, representatives of the Borderland Foundation, professor Alfredas Bumblauskas - a historian, professor Jerzy Axer - a philologist and a philosopher, Leon Brodowski, Ph.D., professor Andrzej Strumiłło - an artist creating his works in Maćkowa Ruda, professor Mieczysław Górski - an ecologist, professor Stefan Kozłowski a geologist, professor Edmundas Zavadskas, Ph.D. Eng., rector of the Gediminas Technical University in Vilnius, doctor Kazimierz Radecki - a pharmacist. The Lithuanian Friendship Club of Poland has participated in organising international conferences abroad, such as "Humanisation of Technology", which was held in Vilnius in 200173. The whole double issue 3/4 of Lithuania in 1997 was devoted to discussing similarities and differences between Lithuanian and Polish cultures.

tódź Cultural Centre and Federation of Creative Associations have maintained cultural cooperation with centres in Klaipeda and Palanga for over ten years. They co-organise artistic workshops, with youth dancing groups, Polish and Lithuanian choirs from Palanga and the Vilnius region visiting Łódź.

In 1992, to commemorate the $120^{\text {th }}$ anniversary of death of Stanisław Moniuszko, a commemorative tablet was placed in the Polish and Lithuanian languages. The Polish Culture Centre in Lithuania was set up in January 1993 in Vilnius. Polish Art Gallery at the editorial office of the From the banks of Neris biweekly was opened on 3 May 1994. Polish Art Gallery organised the prestigious exhibition Art of Lithuania '97), where paintings of contemporary Polish artists from Lithuania were exhibited. The gallery has also hosted promotions of Polish books, e.g. on 29 November 1998 the book by Tomasz Łubieński M for Mickiewicz was presented. In 1998, on the occasion of the anniversary of Mickiewicz, Polish Art Gallery organised the exhibition entitled "We are all from Him". On 11 November 2004 a branch of Polish Art Gallery Vilnius Gallery From the banks of Neris was opened in the Praga quarter of Warsaw. 
In 1995 the Lithuanian government made a decision to construct in Sejny the Centre of Lithuanian Culture, which was opened on 14 February 1999.

After real socialism was overthrown, people who wanted to be publicly active were able to associate in non-governmental organisations. The first issue of Lietuvos bajoras, magazine of the Royal Nobility Association of Lithuania came out in 1995. In the same year the Ministry of Justice of the Republic of Lithuania registered the Congress of Poles in Lithuania. In 1997 the Consolidation of Lithuanian Citizens was established. The organisation made its goal to unite the residents of Lithuania who intend to construct a civil society ${ }^{74}$.

In the 1990s, thanks to establishment of cultural cooperation between centres in Poland and in Lithuania, the audiences were able to admire artists well known worldwide. During the Vilnius Theatrical Meetings of the Polish Stage in 1995 spectators saw the repertoire of theatres from all over the world. In the same year, concerts were given in Vilnius by the world famous cellist Mstisław Rostropowicz, with the company of the Lithuanian National Symphonic Orchestra under the baton of Juozas Domarkas. Films directed by Krzysztof Kieślowski were presented to cinema fans at a review in one of Vilnius' cinemas in 1997. International Poetic Meetings May on the river Neris have been organised regularly. The main organiser of the event, e.g. in 1998, were editors of the From the banks of Neris biweekly. A retrospective of the works of Andrzej Wajda took place in 1999 at the cinemas in Vilnius. During a concert in the Franciscan church under reconstruction in Vilnius, music lovers were able to listen to a concert conducted by Krzysztof Penderecki.

The exhibition entitled Kernave - Lithuanian Troy, prepared by the State Museum-Reservation of Archaeology and History in Karnave ${ }^{75}$, took place in 2002 at the Archaeological Museum in Warsaw, with six hundred most attractive items discovered during many years of archaeological work presented.

Young artists who met in 2003 during the $13^{\text {th }}$ International Theatre Festival Contact 2003, focused on presenting what contemporary theatre speaks about. They staged a play directed by Marius Ivaškevičius, in which he focused on the psychological dimension of characters and not on the situation of Lithuania incorporated into the USSR. In the following year in Torun, during Contact 2004, the audience saw an adaptation of Romeo and Juliet directed by $\mathrm{O}$. Korsunovas from Vilnius, the said adaptation taking place in a pizzeria.

The $1^{\text {st }}$ Festival of Borderland Culture was held in 1995 in Mrągowo, with participation of groups from Lithuania, including Vilnius Region, Concord from Rudamina, bands Vilnius Band and Kaziuka, as well as the Kaunas band Anchor and other Lithuanian artists.

The premiere of Pan Tadeusz took place on 2 November 1999 in the Vilnius cinema Lietuva, and then the film was shown in Klaipeda, Kaunas, Siauliai and Panevezys. The $10^{\text {th }}$ Polish Culture Festivities Go off, Polish song took place in 
Trakai in May 2000. Polish cultural institutions operate in Lithuania in smaller towns as well. The Ethnographic Museum of the Vilnius Region, a Polish cultural institution, was opened in 2000 in Nemencine near Vilnius.

The Lithuanian Evening was part of Theatre Evenings organised in Warsaw's Hackney Cabs House by the Tree of Perun Theatre in 2005. Materials for the preparation of the performance were collected during a trip to Lithuania as well as in the Vilnius archives of the Faculty of Ethnographic and Musical Studies of the Lithuanian Academy of Music.

The premiere of Green Goose Theatre by Konstanty Ildefons Gałczyński took place in 2002 at the Vilnius Old Town Theatre. The actors prepared for staging this difficult play by participating in a course for actors-philologists at Vilnius University. The Old Town Theatre troupe was the first Lithuanian group to perform at the $11^{\text {th }}$ International Theatre Festival Malta 2001 in Poznań. Considered one of the most interesting young European directors, the Lithuanian Oskaras Korsunovas undertook the challenge of staging the play entitled Intuitional improvisations in theatrical space inspired by literature based on Bakakaj by Witold Gombrowicz at the $6^{\text {th }}$ International Gombrowicz Festival in 2004. It was in the same year that Lithuanian artists presented to the spectators their skills during the SEAS Festival in Gdańsk. Gintaras Varnas, director at the Lithuanian and Latvian National Opera House, staged a four-hour performance of Lost Land.

At the official location of the Lithuanian Association of Graphic Artists, the Ark Gallery, fifty prints from the collection of the Library of Nicolas Copernicus University were exhibited. The exhibition was organised in September 2004 on the occasion of signing the official cooperation agreement between Nicolas Copernicus University (UMK) and Vilnius University. The Vilnius gallery From the banks of Neris, branch of the Polish Art Gallery From the banks of Neris in Vilnius, was opened in 2004 in Warsaw. The Gallery has exhibited paintings of Lithuanian painters and people interested in Lithuanian culture were able to participate in various events, such as the Kaziukas. Kaziukas is a traditional Lithuanian celebration in honour of Lithuania's patron, St. Casimir; in tsarist times the holiday was known deep in Russia. Currently, a fair is held on 4 March at the Old Town in Vilnius, with wood, wicker and clay handicraft products sold there. The main attractions of the event are beautiful Lithuanian Easter palms.

The Polish Theatre Znak (the "Sign") presented Forefathers Eve (Dziady) by Mickiewicz at the Lithuanian theatre festival which took place in 2005 in Salčininkai.

In summer 2005 at the Castle Cultural Centre in Poznan one could see the vernissage of works of the most outstanding Lithuanian photographer Antanas Sutkus and Jonas Dovydenas, whose photographs have been published in, among others, National Geographic, Time, Playboy and Chicago Tribune. 
A photographic exhibition entitled Ways to Freedom - through "Solidarity" to Europe was organised in 2005 at the Michat Romer University to accompany celebrations of establishment of the Independent Self-Governing Trade Union "Solidarity". The 2 Polish Corps historical exhibition was opened at the Seym of the Republic of Lithuania.

Polish folklore was presented in Lithuania by the Kurpie Folk Band during its performances in 2005 in Jasziunai and Ajszyszki. Lithuanian folklore regained its importance to Lithuanians thanks to the Skamba, skamba kankliai festival organised each year since 1973. This Lithuanian feast of folk music was a special protest against soviet folklore feasts imposed by Moscow.

Non-governmental organisations deal with integration of the disabled, enabling them to establish Polish-Lithuanian contacts. Such activities are conducted by, among others, the Carpe Diem Tourism and Culture Association, Polish Section for Tourism of the Disabled and Polish Association of the Disabled.

\section{Importance of Polish media to Poles in Lithuania}

Two agreements concerning cooperation of the Television and Radio were signed on 17 January 1992 in Vilnius between Lithuania and Poland.

Broadcasting of the regular half-hour television programme in the Polish language, entitled Panorama of the week began in Lithuania already before the governmental agreements were signed, on 7 August $1989^{76}$. Broadcasting of the Polish programme was stopped during fights around the television tower, but the transmission was restored on 1 September 1990. On 26 November 1993 the Lithuanian Ministry of Communications announced a communication on retransmission of the $1^{\text {st }}$ channel of Polish Television, for which the 38. channel was assigned to be shared with Baltic Television ${ }^{77}$.

The Lithuanian Broadcasting Station of the Polish Radio began its activity at the beginning of 1990s. In Vilnius a private Polish station, From the banks of Neris Radio began transmitting in 1992. In 1998 the Lithuanian Parliamentary Committee for Human Rights and Citizens' Rights reprimanded managers of the National Lithuanian Radio that there were few broadcasts of national minorities on $1^{\text {st }}$ Channel ${ }^{78}$. On 14 February 1999 the broadcasting time of Polish language programmes on the Lithuanian Television was reduced by half.

Currently the auditions addressed to Poles abroad are prepared in Poland at Radio Polonia broadcasting Programme for Listeners Abroad, From the banks of Neris Radio ${ }^{79}$, Office for Programmes for National Minorities at Radio Bialystok. The Lithuanian Radio Magazine is a programme broadcast regularly at Radio Bialystok since $1^{\text {st }}$ March 1990; at the beginning it was a thirty-minute 
programme broadcast once a week, but currently there are two fifteen-minute programmes during the week and a thirty-minute one on Sunday. At the same radio station journalists prepare a half-hour musical programme for national minorities, presenting legends of rock, folk, famous singers, news, etc., entitled Musical Border Zone $e^{80}$.

The Radio Centre for Folk Culture of Polish Radio broadcast in 2004, among other, music of the Lithuanian band Sutaras and of Vilnius Jazz Quartet.

The Polish Radio from the banks of Neris is a regional radio station broadcasting in the radius of one hundred kilometres around Vilnius. It is among the most popular in the Vilnius region. For their services, its journalists were awarded Merit Crosses of the Republic of Poland for supporting Polish culture and education in Lithuania and for supporting Polish-Lithuanian cooperation, promoting Polish culture and delivering information in the Polish language in Lithuania. In 1997 a television programme under the same name was created next to the Radio from the banks of Neris station.

Polish Television financed a documentary entitled Look, Lithuania..., made by Vita Žalakevičiuté-Drygas, for which the Lithuanian side made available archival materials. The film presents stories of individuals, including those of participants of the resistance movement in Lithuania. The film could be seen on the $1^{\text {st }}$ Channel of Polish Television (TVP), and after a few days in the Lithuanian LTV; it was presented in the period from June 1940 to August 1991. Journalists are able to use the resources of the INFORUM Polish Information Centre in Lithuania.

In November 2005 Polish Television prepared a whole-day programme devoted to Lithuanian culture.

The Regional Polish Television in Białystok broadcasts Lithuanian Panorama. Programmes of the TV Polonia are transmitted by earth stations in Vilnius, Elektrenai and through cable TV networks ${ }^{81}$.

Our compatriots in the East value most the printed publications, with press as the most important medium. Polish-language press is subsidised from the funds of the Senate of the Republic of Poland through the mediation of the Foundation Aid to Poles in the East $t^{82}$. Assistance reaches thirty-eight titles which would not be published without the aid from Poland. In general, around fifty titles come out for Poles living in the lands of the former USSR, some of them ephemerally, some of them suspended and then published again. They are mainly irregularly published bulletins and thus they have not been able to win regular readers among whom they would indeed be able to influence the opinion forming process.

Periodicals in the Polish language are published in Lithuania for readers interested in Polish culture: "Vilnius Courier" Polish Daily in Lithuania $a^{83}$, Vilnius Region Weekly ${ }^{84}$, Our Gazette weekly, body of the Association of Poles in Lithuania ${ }^{85}$, Our Time ${ }^{86}$ biweekly, Meetings, Catholic biweekly ${ }^{87}$, "Vilnius 
Magazine" Monthly of Poles in Lithuania ${ }^{88}$, "From the banks of Neris ${ }^{89}$ quarterly, Vilnius Ateneum ${ }^{90}$, Vilnius Gazette $e^{91}$, Calendar of the Vilnius Family" "Friendship" Weekly of the Vilnius Region ${ }^{93}$, Meetings ${ }^{94}$ Catholic gazette, In the Circle of Culture ${ }^{95}$, Vilnius Varietie biweekly ${ }^{96}$, Tabloid News ${ }^{97}$.

"Vilnius Courier" Polish Daily in Lithuania is the only daily which has been coming out for a long time; recently it has celebrated its fiftieth anniversary. The historical and cultural magazine From the banks of Neris is an independently published quarterly whose professional standard enjoys high recognition.

Lithuanian and Polish journalists have organised common training workshops. A four-day seminar for journalists from Poland was held in 1996 in Vilnius, with the participation of journalists from the Polish press, television and radio stations.

Journalists of the Polish-language press established the Association of Polish Journalists in the East "Polish Media - East" 98.

In 2005 there was the total of about fifty titles coming out in the East, with twenty of them published in Ukraine, seventeen in Russia, thirteen in Belarus and eleven in Lithuania99.

The Internet is a medium which has become available to an average user in the last decade. The Internet contains information on meetings where one can get to know the culture of the others. (Materials concerning issues discussed in this article have mainly been obtained from the Internet). An advantage of the internet as a means of communication is the ability to reproduce information available for a broad spectrum of recipients worldwide. Publication of information does not involve high costs and is ecological in comparison with other types of publications.

Polish literature or publications on issues interesting to readers are available at internet libraries, including Polish Internet Library, Library of Polish Literature on the Internet, Treasures of Polish Literature, "ROCK” Religious Library, „Literatura.net.pl" publishing port, Cracow Library and the virtual library of Polish literature $\mathrm{e}^{100}$.

Polish press is available at the sites of among others: Gazeta Wyborcza, Nasz Dziennik, Rzeczpospolita, Super Express, Trybuna, Gazeta Bankowa, Newsweek Polska, Polityka, Przeglad, Przekrój, Tygodnik Finansowy, Tygodnik Powszechny, Wprost, Zielony Sztandar.

Internet users can visit sites of Polish press published in Lithuania: Dziennik Polski na Litwie „Kurier Wileński”, Miesięcznik Polaków na Litwie „Magazyn Wileński”, Tygodnik „Nasza Gazeta”, Tygodnik Wileńszczyzny „Przyjaźn’”, Nasza Gazeta ${ }^{101}$.

The radio From the banks of Neris is available on the Internet at http://www. znadwilii.lt, whereas broadcasts of Radio Bialystok from the programme Border Zone $e^{102}$. 
Polish communities and Poles abroad can download news they are interested in from the site of the Polish Press Agency Polonia for the Polish community. Magazine of news sent in by Poles from all over the world.

One of the statutory objectives of the Adam Mickiewicz Institute is to spread information on Polish culture. This objective is accomplished by, among others, publishing the information on the internet at http://www.iam.pl and http:// www.culture.pl in Polish and English, with some pages at http://www.culture.pl prepared in French and German as well. The Home of Polish Culture in Vilnius makes information on Polish culture in Lithuania available at http://www. polskidom.lt.

Information concerning Lithuanian cultural events is also available in Polish at http://www.Lietuva.It - Lithuania. Lithuanian Central Internet Gates, where one can find Lithuanian internet sites devoted to culture, virtual exhibitions which are currently being presented, latest exhibitions in Lithuania and cultural events in Vilnius in the current week.

Stanisław Korczyński is the owner of a well known Polish bookshop in Vilnius. In Poland, Lithuanian language titles are published by the Aušra (Lithuanian: Aušros) publishing house based in Puńsk ${ }^{103}$.

\section{Education - an important factor of the state's social growth}

Issues of education in Poland and Lithuania are regulated by two bilateral agreements: the Agreement between the Ministry of Education of the Republic of Poland and the Ministry of Culture and Education of the Republic of Lithuania, dated 21 February $1992^{104}$ and the Cooperation Programme between the Ministry of National Education of the Republic of Poland and the Ministry of Education and Science of the Republic of Lithuania for the years 1998-2001, dated 16 October 1998. The very high importance of education for development of relations between the two countries is evidenced in the fact that half of the bilateral agreements concern education ${ }^{105}$.

A dishonourable incident took place on 1 September in Trakai Voke. Even though establishment of a Polish class was agreed upon with the school headmaster, four Polish children and their parents were thrown away from the school by Lithuanian teachers. Nine Polish deputies reacted by submitting to the Supreme Council of Lithuania a vote of no confidence towards the vice minister of culture and education.

On 11 December 1993 the Polish Schooling Association complied with the requirements of the authorities and changed the Polish name, which had been used until that date, to a name in Lithuanian. 
On 7 February 1994 the Seym of the Republic of Lithuania adopted the Act on the Lithuanian state language.

Concluded in Vilnius on 12 December 1999, the „Agreement between the Government of the Republic of Poland and the Government of the Republic of Lithuania on cooperation in the fields of culture, education and science" obliges both parties to pay particular attention to the operation and needs of the chambers of Polish studies at universities in the Republic of Lithuania and of the chambers of Lithuanian studies (or Baltic studies) at universities in the Republic of Poland, especially with respect to mutual employment of lecturers ${ }^{106}$. The both parties undertook to ensure proper conditions of work to the teachers so that they can popularise knowledge of the native language to national minorities in the both countries, as well as their native history, geography and culture, and to increase the standard of teaching. Cooperation covers preparation of teaching curricula and textbooks for the teaching of subjects specified in the agreement ${ }^{107}$. Teachers undergo preparation for teaching the Polish youth at the former USSR republics at, among others, the Main Centre for Teacher Training in Warsaw and the Polish Communities Teachers' Centre in Lublin.

The chamber of Lithuanian studies was opened at the Adam Mickiewicz University in Poznań in 1989. The Lithuanian language, literature and PolishLithuanian relations are university subjects taught at the College of Lithuanian Language and Culture at the Institute of Polish Studies at Wrocław University. Courses of the Lithuanian language are provided by the East European Studies (Studium Europy Wschodniej) of Warsaw University. Curricula of the Lithuanian language were developed by Professor Mieczysław Jackiewicz, Ph.D., on recommendation of the Adam Mickiewicz University in Poznań ${ }^{108}$. Practical courses of the Lithuanian language, historical grammar of the Lithuanian language, descriptive grammar of the Lithuanian language and history of the Lithuanian literature are taught at the Chamber of General Linguistics and Baltic Studies of Warsaw University.

The Polish language and literature have been taught at the Chamber of Polish Studies of Vilnius University since 1 October 1993. The Chamber is headed by Algis Kaleda, Ph.D.

Universities undertake integration activities. The University of Humanities and Economic Sciences in Włocławek began in 2001 efforts to enrol interested disabled Poles from Lithuania ${ }^{109}$ to B.A. and M.A. studies in Revalidation Pedagogy of the Disabled.

In Lithuania there are one hundred and twenty-two Polish schools, thirteen weekend schools and fifty playschools. Three thousand teachers work at the Polish schools, teaching twenty-one thousand learners.

The fact that the schools were opened by representatives of Polish and Lithuanian governments symbolised the cultural cooperation of the two 
countries. On 1 September 1994 the Polish John Paul II High School for over one thousand and seven hundred learners ceremonially began its work in Vilnius, and on the following day the Lithuanian prime minister participated in the opening of a Lithuanian school in the town of Widugi near Sejny.

Organisations functioning under the auspices of the Senate joined the programme of adaptation and construction of school facilities. In Vilnius young people can obtain education at, among others, the Polish Adam Mickiewicz Grammar School, A. Wiwulski Elementary School, J.I.Kraszewski Secondary School, Władysław Syrokomla Secondary School which has worked for over fifty years now and Stanisław Konarski Polish School, whereas the Vilnius facilities for small children are "the Spring” („Źródełko”) and "Neris” („Wilia”). Educational and day-care facilities where children can learn to speak Polish are located in, among others, Suderve, Šumskas, Butrymańce, Senieji Trakai, Baltoji Voke, Kieny, Korew, Jasziunai, Lentvaris, Tabariškes, Turgeliai, Eišiškes, Salčininkai ${ }^{10}$, Buivydziai, Egliszach, Nemenčine, Suderve, Szklary, Dieveniškis, Zujuny, Grigaičiai, Juodšiliai and Ligojnie.

A demonstration of students and university teachers took place on 22 October 1999 by the Seym of the Republic of Lithuania, in protest against reduction of the education budget.

In the middle of 2005, local authorities of Vilnius allocated funds to the renovation of five Polish schools in Vilnius, Vilnius Settlement and they are planning to construct new schools in the other quarters of the city. Funds for renovation of Polish schools and playschools in Vilnius come to a large extent from non-governmental organisations, e.g. from the Schooling Association ${ }^{111}$.

On the Polish side, the Ministry of Education and Science is obliged to properly equip schools with textbooks and teaching aids. At present, the Ministry sends textbooks to Polish schools through the Polish Education Abroad Foundation. The Polish Ministry of Foreign Affairs intervenes in sensitive issues, e.g. it adopted a stance in the dispute concerning textbooks for Polish schools in Lithuania, in February 1992. As a result of the intervention of the Ministry of Foreign Affairs, in July of that year a Polish-Lithuanian Textbook Committee, examining problems in the teaching of history, began work. Polish parliament deputies from the Commission for Education, Culture and National Minorities of the Polish-Lithuanian Parliamentary Assembly visited Vilnius on 23-24 May 1998. Among others, the deputies paid a visit to the Association of Teachers of Polish Schools in Lithuania Schooling Association as well as the Polish schools in Nemenčine and Trakai. Each year, the Association of Teachers of Polish Schools in Lithuania Schooling Association organises a competition for the best Polish school and teachers in Lithuania. On 1 July 1998 president of Lithuania, Valdas Adamkus, visited schools with the Polish and Lithuanian as the official teaching languages. Issues of Polish education, restitution of land and new administrative 
division were discussed during the meetings with the president. In 1999 the Local Government Council of the Sirvintos district adopted a resolution concerning liquidation of the Polish section of the local school, effective at the beginning of the following school year. In the same year, $70 \%$ secondary school graduates ${ }^{112}$ took the optional maturity exam in the Polish language and literature. Positions of Polish schools specialists at Lithuanian educational bodies were liquidated in December 1999. In autumn 1999, the part-time position of Polish language methodologist was liquidated at the Centre for Improving Teacher Qualifications. Simultaneously, the position of senior specialist for Polish language schools and Polish language was liquidated at the Lithuanian Ministry of Education.

Three teachers from Poland worked in Vilnius in the period 1991-1995, teaching the Polish language, history and leading scouting packs. The Consulate General of the Republic of Poland grants awards to the best Polish teachers and schools. Teachers from schools providing Polish language education in the Vilnius region organise conferences to discuss issues important for Polish education in Lithuania, e.g. the conference entitled Polish child in Polish school was held in August 1999. Representatives of universities meet in order to determine their common standpoint regarding academic education. The $6^{\text {th }}$ International Academic Conference Reform of the education system and preparation of teachers was held in September 1999 with participation of scholars from Universitas Wratislaviensis which had cooperated with the university in Vilnius for thirty years.

The Polish Schooling Association in Lithuania organised in 2002 the $1^{\text {st }}$ Forum of Polish Schools in cooperation with the Polish Community, Consulate General of the Republic of Poland in Vilnius, departments of education of the Vilnius and Šalčininkai regions, in order to exchange experiences and opinions among teachers. The $4^{\text {th }}$ Forum of Polish Communities Education was held on 4-9 September 2002, and problems of Polish communities' education were discussed there. Delivered speeches concerned education of the Polish youth in Lithuania, including Specific issues of Polish education on the early school level at Polish schools and Polish schooling in Lithuania in the post-war period.. Lithuania records a high level of national identity of Poles, with as many as $85 \%$ of them declaring Polish as their native language in 1989 year.

Currently, Lithuanian authorities offer to national minorities, including the Polish minority, good conditions of studying at schools where only Lithuanian is the language of teaching. At those schools there is a danger that Polish children will not be able to study correctly their mother tongue. Polish schools are insufficiently equipped. Maintaining a good standard of education at Polish schools ought to be treated as a priority, important for good PolishLithuanian relations. In rural areas, the school is often the only centre of Polish culture ${ }^{113}$. 
Entry exams for university studies in Poland for graduates of Polish schools from the Vilnius region took place in May 1998 with participation of representatives of the Ministry of National Education and the Consulate of the Republic of Poland.

In a long-term perspective, a balanced standard of school education will be an important factor with significant influence on sustainable social growth of Lithuania.

The contacts of learners and exchange of teachers' experiences resulted in establishment of contacts between among others the Vilnius J.I. Kraszewski Secondary School with the $27^{\text {th }}$ Janusz Korczak Elementary School in Gdynia; of Secondary School of the Jesuits in Vilnius with the vanguard experimental secondary school of the Jesuits in Gdynia. Thanks to their contacts, Polish children from Vilnius are able to acquaint themselves with Polish customs and friendships between families begin. The European Meeting of Polish Communities' Youth was held on 8-9 October 2004 in Vilnius, attended by young people from ten countries.

Polish non-governmental organisations undertake regular care over schools in Lithuania and school youth from Lithuania, e.g. the Association of Friends of Hrodna and Vilnius ${ }^{114}$ performs custody over students of the Teacher College in Ostrołęka.

The SEMPER POLONIA Foundation awards scholarships to students from Lithuania who were enrolled to study in Poland. The SEMPER POLONIA Foundation and the Polish Olympic Games Committee have organised, based on regulations of operation of Polish School Youth Olympic Athletes' Clubs, eighteen Polish Community School Olympic Athletes' Clubs and the "Olimpic" was established in Lithuania at the John Paul II Elementary School in Vilnius. The Clubs may operate at Polish schools, schools providing education in the Polish language and at Polish community organisations. The Foundation organises contests for young people in many domains, e.g. Let's save them from being forgotten, in which young Poles from all over the world take part. The aim of the contests is to make Polish youth interested in the history of Poland and to make them aware of significance of the Polish contribution into the economic and scientific development of other countries. Moreover, Polish youth meet during days of Young Animators of Sport and the SEMPER POLONIA Scholarship Holders' Clubs which unite those young people in Lithuania who participate in educational programmes.

The Ministry of National Education concludes agreements aimed at establishing cooperation of youth organisations with, for example, the Lithuanian National Youth Council. The Lithuanian Education Centre in Sejny will include a playschool, elementary school and grammar school with Lithuanian as the official language of teaching. Financial problems hinder the opening of the centre ${ }^{115}$. 
Polish and Lithuanian youth were able to integrate during common theatre workshops where they prepared the staging of A Midsummer Night's Dream directed by Zbigniew Szreder. The premiere of the play took place at the Elementary School in Egliszki in August 2005, and on 1 September it was performed at the Centre of Schools of General Education № 5 in Gdańsk. The teachers from Egliszki organise excursions to Poland for their students.

Polish media in Lithuania treat the educational issues as important for development of the community. Radio From the banks of Neris broadcasts a regular programme entitled Polish schools in Lithuania: achievements, problems, prospects. Importance of education development to our region in Europe is currently reflected in Gdańsk University's Long-Term Programme for Construction of the Baltic Campus.

The project justification stresses increased interest and growth in the number of students along with strong competition from other academic centres located around the Baltic Sea, such as Stockholm University, Helsinki University and Vilnius University.

John Paul II reminded the Bishops Synod's appeal: "Set up a voice, when human rights of people, minority and nations are trample (...) do not spare effort to assure young generation the future, what will be worthy a man by work, participation in culture and upbringing to mental and moral worth.

\section{Tightening of local cooperation undertaken on the citizens' initiative ought to be the basis of international cooperation}

The Seym of the Republic of Lithuania adopted the "Act on Ratification of the Framework Convention of the Council of Europe on Protection of National Minorities" dated 17 February 2000, № VIII-1548.

"The Act on Education”, valid since 2 July 1998, ensures to national minorities the right to have their own playschool facilities and schools of general education ${ }^{116}$ provided that citizens submit a respective request and that the request reflects actual demand (point 2).

The new draft of an act concerning decision on the language of teaching at schools was submitted to the Lithuanian Seym on 28 January 2005. Poles collected twenty-five thousand signatures under the petition in which they rejected changes introduced on the strength of the new act and allowing local authorities to make decisions concerning the language of teaching at local schools.

Wladysław Czapliński ${ }^{\mathrm{C}}$ stated that the principle of precedence of Community law over the domestic law means that the domestic law may not justify failure to

c Władysław Czapliński is an expert in international public law and in European law, Professor, Ph.D. in legal sciences. 
comply with international obligations. The above does not undermine the superior nature of the constitution. Validity of legal means undertaken by the Community can certainly be only evaluated in the light of the Community law. One may not question validity of that law quoting the contradiction of a Community norm with the constitution. The Community law operates directly as long as it meets formal requirements resulting from the primal law ${ }^{117}$. Protection of fundamental rights is a requirement of the Community law as they belong to the common constitutional heritage of member states ${ }^{118}$.

Historical traditions may be a factor encouraging establishment of cooperation between the nations in the conditions of contemporary Central and Eastern Europe. Habits of the former Cracow-Vilnius tract are discussed during the series of quarterly meetings entitled Lublin - between Cracow and Vilnius in Lublin, a city located on that tract. The meetings are organised by, among others, the Cultural Centre and Historical Museum of the City of Lublin. Moreover, lectures present the role of Lublin and its influence on the conditions of social and economic development of the region, e.g. the lecture Lublin - empire of European trade in $14^{\text {th }}$-16 $6^{\text {th }}$ Century by Professor Ryszard Szczygieł of the Maria Skłodowska-Curie University (UMCS). UMCS participates in accomplishment of activities connected with the international tourism route Lublin-Vilnius Route and the city's Route of Architectural Monuments. The symbol of reconciliation of nations living in the Lithuanian land is the Monument of Exiles in Naujoji Vilnia. An inscription in four languages - Polish, Lithuanian, Hebrew and Russian - was placed at the foot of the monument.

Bonds between people appear thanks to tightening regional cooperation, undertaken on the citizens' initiative. The legal acts which regulated this issue were agreements on mutual trade and economic cooperation between Poland and Lithuania, signed by the ministers of economy on 27 February 1992 in Warsaw. Lithuania's minister of economy described Poland as the "gateway to Europe".

Universities have also begun to contribute to establishing cooperation between businesspeople. Nowadays universities organise exhibitions which present achievements and their objective is for common economic projects to be undertaken. In 2005 the Wrocław University of Technology organised the exhibition entitled Days of Science and Technology Poland-East, whose message was to enable scientists to commercially present their achievements and to initiate cooperation based on new technologies and innovations among businesspeople from Poland, Ukraine, Belarus, Russia, Lithuania and others Baltic States. In 2005, technicians and engineers of Polish origin came from all over the world to the meeting Poles together at the Polish Culture Centre in Vilnius, organised by the Association of Construction and Sanitary Engineers and Technicians in Vilnius. The main topic of discussion was the contribution of Poles to the European technical civilisation. In 2003 Presidium of the Senate of the Republic of Poland 
entrusted the Chief Technical Organisation of the Federation of Scientific and Technical Associations with the state assignment with respect to custody over the Polish communities and Poles abroad.

Since 1995, the Polish-Lithuanian Chamber of Commerce has each year organised fairs where Polish and Lithuanian businesspeople have been starting their cooperation, e.g. in 1995 the international fair in Kaunas saw one hundred manufacturers.

Cooperation of partner towns of Poland and Lithuania is negotiated during the Polish-Lithuanian Local Government Forums ${ }^{119}$. Agreements for beginning partner cooperation have been signed between, among others: Gdańsk and Vilnius, Gdynia and Klaipeda, Biłgoraj and Kelme, Częstochowa and Siauliai, Elbląg and Druskininkai, Gołdap and Sakiai ${ }^{120}$, Grodzisk Mazowiecki and Radviliskis, Lublin and Panevezys, Łódź and Vilnius, Mrągowo and Trakai.

The scope of cooperation between Polish and Lithuanian cities will be presented on the example of Elbląg and Durskininkai. Elbląg's proposal of partnership was immediately accepted by the Lithuanian mayor of Druskininkai at that time, Vytautas Janonis. The agreement was signed in April 1996; on the Polish side, particular involvement was shown by the Lithuanian-origin staff of the Elbląg Town Hall. Both parties declared their will to cooperate in the fields of public utilities, as well as education, culture, services and youth exchange. An example of cooperation is the one-week training trip to Elbląg for cooks and waiters from Druskininkai in order to get to know the Polish cuisine. After Lithuania regained independence, Druskininkai lost its patients from the former USSR but became more frequently visited by Poles. The training was highly beneficial for the Lithuanian side as Druskininkai recorded a high rate of unemployment at that time ${ }^{121}$. Cooperation of the two towns consists in exchange of children and youth for summer camps, common organisation of exhibitions of visual artists, performances of the Song and Dance Band "Elblag Land", as well as artistic and sport groups, Days of Elblag in Druskininkai and the Days of Druskininkai in Elbląg. During the floods in Poland in 1997, thanks to the intermediation of Elbląg, the authorities of Druskininkai hosted forty children from Opole. In order to facilitate learning Polish to the children of Polish origin, living in its partner towns: Druskininkai, Navahradak and Ternopil, in 1998 the City Concil of Elbląg funded three scholarships for secondary school graduates from those towns who would begin studies at the State School of Higher Professional Education. On the other hand, Poles have learned from the Lithuanians to bake the Lithuanian black bread which has well deserved its reputation. The recipe for the "Lithuanian bread" was received from Druskininkai by PSS "Społem" from Elbląg, which is the producer of this bread in the local market ${ }^{122}$.

In 1996 Gołdap in Poland housed the International Conference for Local Governments of the borderland regions of Poland, Lithuania, Russia and 
Belarus, whose aim was to determine the conditions of regional cooperation in the European Union. Thirty different events took place in Lithuania in the same year within the framework of the Days of Poland, organised by the embassy of the Republic of Poland. In order to boost cooperation on the local level, the Association of Borderland Regions of Lithuania, Belarus, Poland and Russia was established in 1997. Members of the Association intended to develop cooperation in the fields of economy, tourism, education and culture. The first Lithuanian-Polish Forum of Local Governments took place in Warsaw in 1998. Its participants considered it to be an important event.

The Association of Local Governments of the Region of Sejny established the Polish-Lithuanian Chamber of Tourism and Cultural Heritage, which received the approval of the Polish-Lithuanian Inter-Governmental Commission for Cross-Border Cooperation in Gołdap in 2000. The Polish-Lithuanian Chamber of Tourism and Cultural Heritage deals mainly with rural tourism but its members can also become entities dealing with eco-tourism: ecological agriculture, folklore and ethnoculture. On the Polish side, the Chamber is based in Sejny, and on the Lithuanian side - in Lazdijai. Entities from Latvia and Ukraine are also interested in the activities of the Chamber, and written contacts have been established ${ }^{123}$. In May 2000 members of Polish cooperatives came to Lithuania in order to get in touch with the Lithuanian Association of Cooperatives of the Food Industry. In June of that year a group of one hundred and twenty-five members of local Polish authorities visited the Local Government of the city of Vilnius.

Small breweries, family-owned or run by groups of several people, are currently developing in Vilnius, Kaunas and other cities of Lithuania; in many cases they sell beer to be consumed locally at cosy beer bars by the breweries. While tasting it, guests can acquaint themselves with the process of brewing the beer and listen to the history of the brewery told by its owners. The „Busi Trečias” beer bar in Vilnius is located in an old one-storey building near the Old Town.

Cooperation on the state level enables both sides to implement the achievements of national cultures and regulates the issues which are important and useful in everyday life, such as trade contacts, mutual exchange of technological solutions, food products and development of ecotourism.

Leaflets and materials promoting a given kind of economic activity are published in several languages; in the Polish-Lithuanian borderland areas businesspeople sometimes give the Polish and Lithuanian versions of their family names, e.g. in the leaflets published in Polish, Lithuanian and English by the Town Hall in Puńsk or advertising materials such as those of, for example, eco-tourism farms ${ }^{124}$.

Eco-tourism is a form of business which has particularly high development prospects in Lithuania thanks to the advantages of its nature as well as clean and peaceful lake districts. The Lithuanian Centre for Promoting Rural Tourism in Kaunas $^{125}$ has been established in order to support rural tourism. The National 
Centre for Tourism Information of the Republic of Lithuania ${ }^{126}$ operates in Warsaw.

Scientists from Warsaw Agricultural University cooperate with Vilnius Agricultural Academy in Baltoji Voke, commonly preparing a programme for development of ecotourism in the Vilnius region, in the neighbourhood of Šalčininkai.

On the occasion of the $200^{\text {th }}$ anniversary of birth of Adam Mickiewicz, the Bank of Lithuania issued in 1998 silver coins of fifty litas, designed by Algirdas Bosas. For the anniversary, the Academy of Sciences of Lithuania organised the conference entitled Adam Mickiewicz and Lithuanian romanticism.

My emotional bond with Lithuania began forming as early as in school when I needed to understand why the Polish national poem begins with the words "Lithuania, my Homeland” („Litwo, Ojczyzno moja”).

The $15^{\text {th }}$ Chopin Competition in Warsaw ended last month. Lithuanian pianist, Victoras Paukštelis, advanced to participate in this competition of world renown. Admirers of Chopin's music in Vilnius are associated in the Chopin Association. In 1999 Lithuanians celebrated the Year of Chopin, and its inauguration took place at the Musical Academy of Lithuania. Pieces of Chopin's music were played by Professor Jerzy Godziszewski of the Musical Academy in Bydgoszcz. It was Chopin, Słowacki and Moniuszko that the exhibition Polish Poster, opened in May 1999 at the National Library of Lithuania, was devoted to. The piece of music by Fryderyk Franciszek Chopin, in which the composer used Lithuanian folklore, is Lithuanian song (Piosenka litewska) for vocal and grand piano, with Lithuanian folk lyrics; the lyrics were translated by Ludwik Osiński ${ }^{127}$.

In this article I have presented events connected with culture which influence the formation of contemporary Polish-Lithuanian relations. Currently the attitudes of Lithuanians and Poles strongly relate to tradition and history which are the sources of indigenous values of each nation. It is essential to convey the national values to the next generations so that they can relate to those values in their lives. Values important to the nation are the fundamental grounds on which relations between people from the countries of Central and Eastern Europe will be based in their everyday cooperation in the conditions of the European Union and progressing globalisation. Representatives of the younger generations certainly have many new opportunities to enhance their quality of life, but at the same time they face great challenges. Using the national experience, young generations should follow the message contained in the poem of Adam Asnyk, Polish positivist poet: „One must proceed with the living, grasping a new life, and not dress one's head stubbornly in withered bay leaves". 


\section{Endnotes}

1 Thomas Venclova, professor in the Yale University (USA).

2 T. Venclova: Poeta doctus. edit. by M. Kruczkiewicz. [Academic Voice, internet periodic published by Nicolas Copernicus, Torun in Poland].

3 Another version of his family name: Wolonczewski. Based on: Polish Literature. Encyclopaedic Handbook. Warszawa 1984 t. 1 p. 592. Lithuanian Centre of National Heritage, http://www. pk.org.pl.

4 J. ZaWADzki: Project system of Polish Bookselling in the Congress Kingdom in Poland. Warsaw 1930 p. 28.

5 M. MLeKicka: Publishers of books in Warsaw in partitioned Poland. Warsaw 1987 p. 23-25.

6 Cz. Mrıosz: So that the spirits of the dead leave us in peace...

7 Ibidem.

8 Vilnius was held in reputed a world-wide fame centre of Jewish publishers, judges considered that on that score only New York could rival Vilnius. At present the Jewish Historical Institute in Vilnius deal with collection and research folk culture of Vilnius and neighbouring shtetl, JIVO in New York is an institute, in which Vilnius saved archives are preserved.

9 General Lucjan Żeligowski the commander of Lithuanian-White Russian division on 9th October 1920 year occupied the region near by Vilnius to create "Middle Lithuania". Decision of the treaty signed in Ryga did not concern Vilnius region. During political and economic transformation in January 1992 year in "Middle Lithuania" indicative elections were realized, people, who were not Poles, boycotted them. Indicative Seym passed the unanimous resolution concerning annexion "Middle Lithuania" to Poland and on $20^{\text {th }}$ February 1920 year, and on $24^{\text {th }}$ April 1992 year resolution concerning incorporation the area to Poland. Not till the Council of Ambassadors ratified the eastern border granted Poland the region Little Poland and Vilnius Region. Lithuania did not accept decision concerning annexion of Vilnius and announced that war state with Poland would last until return Vilnius to Lithuanian State.

10 Publisher from the conference: Resistance totalitarian systems in Vilnius region during the Second World War. edit. by Piotr Niwiński. Gdańsk 2003.

11 Assistant professor Algis Kaspervicius, a represent of the Vilnius University, presented the problems connected with Polish and Lithuanian partnership from the point of view of the Lithuanian historiography in his lecture Present Lithuanian historians about the matter of Vilnius and Polish and Lithuanian relationship from 1918-1940 and changes in orginary consciousness of Lithuanian people and also dr Rimantas Miknys, a represent of the Institute of Lithuania, read out his lecture Lithuanian Historiography towards nationalistic problems in the early part of twentieth century. Dr Adam Dobroński, a represent of the Białystok University, presented attitude of Polish historians in his lecture The Bold Line with Reference to Polish and Lithuanian Partnership, which aroused scientists interest. In 2005 year during the international conferency Polish and Lithuanian Partnership in twentieth century historians and politic scientists discussed problems of the both countries. The conference was got up by Universitatis Nicolai Copernici in Torun.

12 H. Wizner: Lithuania. History of Country and Nation. Warsaw 1999.

13 The Polish underground army of the Resistance Polish underground army of the Resistance Movement during the nazi occupation in World War II with its Commander-in-chief in England.

14 T. Venclova: Poeta doctus...,

15 The mentioned project was realized owing to financial support of UNESCO, in framework of worked out "Encyclopaedia of Central and Eastern Europe".

${ }_{16}$ The project subsidized by e.g. the European Commission, UNESCO and the State Committee for Scientific Research. 
17 The problem was discussed during the sceintific conference "Resistance totalitarian systems in Vilnius region during the Second World War", what took place in Warsaw in 2002 year.

18 On $7^{\text {th }}$ October 1988 year it was published the vote of the Presidium of the Highest Council of the Lithuanian Socialistic Soviet Republic "Of Status of Lithuanian Language", which instituted Lithuanian as official language. On $19^{\text {th }}$ November 1988 the Presidium of the Highest Council of the LSSR "Of Using of Lithuanian Language and Other Languages" $26^{\text {th }}$ January 1989 year they were published two decrees of the Highest Council of the LSSR "Of Using of Official Language of the LSSR". $12^{\text {th }}$ February 1989 year it went on in Vilnius protest public meeting against using Lithuanian as official language. It was organized by the organization Jedinstwo under the banner of "We do not want to be citizens of the second category". People had threatened the government of strikes if the decree would have went through. While visiting from 26-28 th June 1989 year A. Brazauskas met with members of the the Lithuanian Friendship Club of Poland, which gave the memorial to him consisting postulates Poles from Lithuania addressed Lithuanian authorities. Seym Council Sajudis deliberated on $5^{\text {th }}$ September 1989 year in Vilnius. People were appealed to placidity and unity, forecast withdrawing controversial the project of act of citizenship in Lithuania. On $6^{\text {th }}$ September 1989 year during extraordinary session of the Council of People's Deputies of Soleczniki Region it was decelerated Polish national and territorial region. It was declared possessing equal rights: Polish, Lithuanian and Russian. From 22-23 September during the session of the Highest Council of the LSSR passed a resolution dealing with the new project of act of the Lithuanian citizenship.

On $7^{\text {th }}$ October "The Red Flag" published different statements estimating attempt of creation of two Polish autonomous territorial regions. On $23^{\text {rd }}$ November 1989 year it was enacted national minorities. From 19-20 December 1989 year during XX Congress of the Communistic Party of Lithuania A. Brazauskas criticized hitherto pulled policy towards in relation to Poles living in Lithuania to ascertain "Lithuania was and it will remain multinational and tolerant". On $26^{\text {th }}$ July during the session of the Municipial Council of Vilnius Region it was passed "the status of the Vilnius Polish Region of Nationality in enter into the composition of the Republic of Lithuania. On 20 $0^{\text {th }}$ September 1990 year in "Vilnius Daily" it was published the open letter of the Board of the Lithuanian Friendship Club of Poland "Into Consideration of Lithuanian Poles and Lithuanians". $6^{\text {th }}$ October in Ejszyszki it was took place the second Congress of Deputies of Municipial Councils of Vilnius Region, during that it was enacted "Of the Proclamation of Polish Nationalistic and Territorial Polish Country composed of Vilnius and Soleczniki Regions", delegates declared that Lithuanian and Soviet treaty signed on $10^{\text {th }}$ October 1939 year on the grounds of Vilnius had been transmitted Lithuania was illegal. About $10^{\text {th }}$ October 1990 year it took place the session of the Councils of Soleczniki Region, the participants supported the resolution of Second Congress in Ejszyszki from $6^{\text {th }}$ October. It was enacted of the equality of rights of three languages: Polish, Lithuanian and Russian in the region and creation of the Adam Mickiewicz Museum. On $22^{\text {nd }}$ January 1991 year by the Chief State Council "Of changes by the Lithuanian Council of the act about national minorities" (declared 23 November 1989 year). It was introduced important and profitable changes for Polish minority: the right to studying in Polish language in academical educational system, possibility of introduction of the language of national minority in offices and information - boards on the grounds of uniform settlements of the national minority and the right to foundation of cultural and educational institutions. Some people admitted to the decision as dictated by the existing state of affairs on account of the approaching oncoming $9^{\text {th }}$ February 1991 year. It was passed a resolution "Of conclusions of the State Commission for affairs of Eastern Lithuania", in which they were declared working out projects: Vilnius administrative district (consisted of two regions: Vilnius and Soleczniki) till $31^{\text {st }}$ May 1991 year, the status of Vilnius district and the possibility of academical graduation by the national minority. Those decision were very anticipated. In practice they remained the dead letter. On $4^{\text {th }}$ September 1991 year during the session of the State Commission they were 
enacted "Of lawful situation of foreigners in the Republic of Lithuania", "Of immigration", "Of amendments to a bill of the emblem of the Republic of Lithuania" and the vote "Of dissolution of commission of the Regions: Soleczniki, Vilnius and Sinieckus housing estate placed in Ignalinski Region. The last one moved deputies of Polish fraction to resolved protest, whom notified the declaration of inconformity of the bill of law and they order to cancel it. After some days the Union of Poles in Lithuania sharply protested. $5^{\text {th }}$ September they were resumed the official diplomatic relation between Poland and Lithuania. "The New York Times" published message concerning rehabilitation of war criminals. It had reference to Lithuanians from $12^{\text {th }}$ ancillary battalion committed slaughter of Jedwishes during the Second World War. The both matters came into notice on the arena of international politics and the harmed Lithuania. During the official visit in Poland the Lithuanian delegation met with the delegations of the Seym and of the Senat, Polish and Lithuanian sides accepted a joint communique relating to the state of affairs of national minorities in the both countries. On $19^{\text {th }}$ December of 1991 year the Polish Foreign Minister pointed out affairs, which Polish side admitted them to be alarming: suppression of Polish program in the Lithuanian TV, announcement of suppression of retransmission of $1^{\text {st }}$ program Polish TV. The Lithuanian side denied that they would be going to break transmission of Polish programs. The canal used for retransmission of Polish TV was directed to at that time created Television of Eastern Lithuania. On $22^{\text {nd }}$ January 1992 year the Chief Board of the Union of Poles in Lithuania and the Polish Franction issued a proclamation addressed the State Commision, it contained claims of realization of former acts of the State Council, most of them were passed in January 1990 year. On $2^{\text {nd }}$ February 1992 Chief Board of the Union of Poles in Lithuania addressed the open letter to V. Landsbergis, L. Wałęsa, G. Vagnorius and J. Olszewski regarding not in conformity with Polish and Lithuanian "The Declaration" as contradictory to affairs of Lithuanian people. They took up historical doubts in the very emotional way to criticize Polish policy towards Lithuania 1918-1940. In 1940 year it was not the Polish State. On $7^{\text {th }}$ February Lithuanians attacked the picket organized by the Civic Committee of Defence of Poles living in the Vilnius Region. $20^{\text {th }}$ February it was published in "Słowo Powszechne" the interview of the primate of Poland Józef Glemp granted the Lithuanian Agency ELTA. Glemp declared that Poles wanted to "understand our brothers Lithuanians" and "we should forgive each other". On $22^{\text {nd }}$ February 1992 year on X Session of Consultative Seym of Lithuania it was criticized submission of Lithuanian administration towards Polish side, "Declaration" was to prove it.

$31^{\text {st }}$ January 1992 year the State Council passed the bill "Of orthography and names and families in idenity cards of a citizen of the Republic of Lithuania". The Seym of the Republic of Lithuania passed the bill "The act of national language passed on $31^{\text {st }}$ Janauary 1995 year", in the $2^{\text {nd }}$ point of that Lithuanian language was settled native language of the Republic of Lithuania. On $10^{\text {th }}$ March 1992 year Polish press expressed disquaiet about Polish handbooks' matter. Afterwards it was explained that all handbooks had to obtain acceptance of the Ministry of Culture and Education of Lithuania. Pupils used Polish literatury and handbook of history as educational equipment. 19 March representative of Polish Foreign Ministry enumerated difficult matters in Polish and Lithuanian relations: altercation of handbooks, accusation of Polish deputies of anti-State activity and discrimination of Poles e.g. plans of settlement with Lithuanian people in Gudele country, $21^{\text {st }}$ March members of the "Vilnija" Society in Vilnius protested against "over-gentle" Lithuanian administration's policy towards Poles. Arrangements with Poland were criticized, Poles were accused of intention of expension. For explaining upon the matter of handbooks Polish - Lithuanian school-bookish Commission was created, its first session took place in Vilnius from 1-2 July 1992 year. The school-bookish commission did research works on teaching history problems. On $10^{\text {th }}$ August 1992 year Poland suppressed visa duty for Lithuanian citizens. 14 $4^{\text {th }}$ January 1997 year round-table discussion went on in the House of Commonwealth of Nations in which representatives of twelve political parties and organizations 
functioned in Lithuania. The Polish Seym passed the bill concerning creation of PolishLithuanian Parliamentary Assembly. During the session of Polish Parliament the president of the Polish Seym was present in the conference room: it was not appointed none of representative of the Election Action of Poles in Lithuania to the Parliamentary Assembly. Two Poles entered the Parliamentary Assembly as members of Lithuanian parties. During the visit in Warsaw in December 1997 year the president of the Foreign Affairs Committee of the Seym talked work of Polish-Lithuanian Parliamentary Assembly over with the new leadership of the Seym of the Republic of Poland. On 25 $5^{\text {th }}$ March 1998 year Lithuanian-Polish Commission as regard National Minorities Problems. Held a council on national affairs on $25^{\text {th }}$ March 1998 year in Warsaw. On $16^{\text {th }}$ December of 1998 year the I Court of Justice of District in Vilnius decided that the Council of Vilnius Administration's bill dated $12^{\text {th }}$ December 1977 year of using, Polish language beside Lithuanian in the region lived by Poles become void. Based on: Lithuanian Annals 1988-2000... Lithuania $1990 \mathrm{nr} 1$ s. 103-129.

19 Paulius Sangavičius is responsible for contacts between the institutions, a lecturer of Academy of Music, a director of Faculty of Culture. Based on: Lithuanian Annals 1988-2000..., s. 49.

$2018^{\text {th }}$ May 1989 year the Chief Council of the Lithuanian Socialistic Soviet Republic passed the unprecedented bill of suspension of the decree of the Presidium of the Chief Council SU on the region of Lithuania (the decree concerned on tax affairs). From 18-19 May in Vilnius XI session of the Chief Council of the LSSR occurred. "The Declaration of supreme power of Lithuania" and they were passed the bills of changes in the Constitution of the LSSR (articles: $11,31,37,70$ ) and "Of causes for economic independence of LSSR" laying down the sole right of Lithuania to: estates, natural resources, and also the State property was present in territory of the Republic. It was passed the decree of the Presidium of the Chief Council "Of using the national language of the LSRR". On $11^{\text {th }}$ March 1990 year in the session of the Chief Council they were passed "The act of the Republic of Lithuania of the restoration of the sovereign State of Lithuania", two acts "Of designation the emblem of the State" and restoration the Constitute of the Republic of Lithuania dated $12^{\text {th }}$ May 1938 year, in which some articles were suspended at once. V. Landsbergis was appointed to the President of the Chief Council of the Republic of Lithuania, whom sent the telegram to notify Michail Gorbachov of the revival of the Lithuanian State. Kazimiera Danuta Pruskiene was appointed to the Lithuanian Prime Minister. Response of world opinion was the indication of necessity of agreement between Poland and Lithuania. 15 $5^{\text {th }}$ March 1990 year the Polish government published the declaration regarding Lithuania. The Polish government assented the base of the self-determination of nations and expressed interest in good relationship with Lithuanian people. The Polish government did not appreciate the Lithuanian State. $21^{\text {st }}$ March the Lithuanian government acknowledged the Red Army as "occupation forces" of not regulated legal status and which had caused great injuries in Lithuania. The following day two acts were passed: "Of the government of the Republic of Lithuania" and the next one concerning the creation of Lithuanian Radio and TV come under the government and appointment of the General Public Prosecutor of the Republic. $11^{\text {th }}$ April the first Government of the Republic of Lithuania was sworn. $23^{\text {th }}$ March in Vilnius it went on the demonstration of the Soviet armed forces. Reaction to the event it was declared the pronouncement of the Council of the Baltic States, in which the Soviet government was called upon to desistance from the military intimidation and bringing pressure to bear on Lithuania. $25^{\text {th }}$ March the Soviet army occupied to next buildings in Vilnius, which belonged to the Communistic party, "at the Communistic Party of Lithuanian's request". In the night $27^{\text {th }}$ the Soviet ranger attacked two mental hospitals, on which there were hoisted flags of the Red Cross: in Vilnius and a locality laid eleven kilometers away from Kaunas. The Chief Council of Lithuania positively protested "unjustified aggression" in the letter addressed the Soviet President M. Gorbachov. At that time in Vilnius it inhabited Polish delegation of the Citizen Parliamentary Club consisted of deputies and senators, whom declared acceptance of the Polish 
and Lithuanian border. The Soviet White Russian Republic leaderships foretold that if the Soviet army had turned away from Lithuania, White Russian authorities would have come out with a claim to return grounds, which in 1940 year were disconnected the White Russian SSR and connected to Lithuanian SSR. On $30^{\text {th }}$ March Soviet rangers occupied buildings in Vilnius: the office of the State Attorney, the Institute of History of the Party and the Press House. $8^{\text {th }}$ April on Palm Sunday a chain of people closed round the Press House in Vilnius in protection against the Soviet soldiers. Owing to purposeful people's attitude the army withdrew. $20^{\text {th }}$ April the Soviet soldiers marched in a printing-house in Maironio Street and they beat some persons. Afterwards the Soviet authorities began introduction economic restrictions in relation to Lithuania: on $18^{\text {th }}$ April supplies of petroleum to oil distillery in Mozejki were stopped, the iron ration of the stock ran out after five days since beginning a blockade, supplies of earth gas were reduced to about $16 \%$ former supplies, groceries (e.g. sugar), wood, metals, chemicals and imported goods. Regulation of food was initiated in April: allowance per person in two months: 2 kilograms of flour, celeals and sugar, 1 kilogram macaroni and salt, $250 \mathrm{~g}$ margarine or lard. Since $25^{\text {th }}$ April Lithuanian journalists had to reduce circulation of Lithuanian press owing to press titles were suspended. The blockade kept up by authorities of the Soviet Union till $30^{\text {th }}$ June. On $4^{\text {th }}$ July Moscow disrupted a blockade of railway in Lithuania. 22-23 June people form Vilnius united round a building of the Record Office of the communistic Party of Lithuania not to give access to take over and dispose of the archives by the Soviet soldiers. On 8 March 1991 year the Council of the Baltic States protested obligatory recruits in their countries to the Red Army. The Finnish Foreign Affairs Ministry declared, that Finland declared citizens of those Soviet republic, whom deserted the right sojourn. In night-time $12^{\text {th }}$ January the Soviet landing troops occupied the building. On $13^{\text {th }}$ January "on bloody-Sunday", the special detachment of the Soviet Ministry of the Interior "Alfa" attacked the building of the Committee of Radio and TV and the TV tower in Vilnius. Fourteen people were killed, in February one more person whom was hurt in those days. The curfew was initiated.

The following day the Soviet soldiers occupied the broadcasting station in Vilnius. The Soviet government declared "the bloody Sunday" was none of their doing. It was devolved the responsibility for "the bloody Sunday" on a commander of garnison. $15^{\text {th }}$ January in their own declaration the Polish government protested the using violence in Lithuania. About two hundred people took part in the funeral procession of people killed "on bloody Sunday", among others: delegation from the Soviet republics and from Poland. The tragedy in Lithuania met with the resolved reaction in the world. The Foreign Commission of the European Common Market transferred negotiations to a later date on bilateral cooperation with the SU, the European Parliament delayed the talks about food aid for the SU fixed the price six hundred and eighty million dollars. The Polish Foreign Affairs Minister said that "they exists possibilities of creation in Poland information centers of the Baltic States [in the period of Soviet administration]". It was the undermost government level of the bilateral relations. $22^{\text {nd }}$ January 1991 year Alina Kurkus arrived to Vilnius the first correspondent the Polish Press Agency, whom was the first journalist, representative of the foreign press agency in Lithuania. On $24^{\text {th }}$ January the Senat of USA with one voice passed a resolution disapproving of policy of the Soviet government in the Baltic State [in the period of Soviet administration] and called upon the President to possibility of applying of the economics' sanctions if Moscow did not change the policy regarding the Baltic States. The British Prime Minister said the British government would stopped all aid for the SU, if Moscow continued policy of violence regarding the Baltic States. Sweden, Finland and Iceland demanded the explanation of circumstance of events in which nineteen people in Lithuania and in Latvia were killed form the Soviet government. $25^{\text {th }}$ January in Vilnius the Soviet commandos shooted at the car with two deputies, 27 January unknown perpetrators shooted at and demolished Lithuanian custom-houses. $1^{\text {th }}$ April a fifteen old boy was killed in Vilnius. On $9^{\text {th }}$ February 1991 year it took place sounding (not referendum) regarding the independence of Lithuania 
and its results confirmed will of Lithuanian people to own independent state. The result of voting was reception of the Constitution Act by the People's State Council "Of the Lithuanian State", in which Lithuania was named "The Sovereign democratic republic" that state was the corner stone of the new Constitution of Lithuania. The first government, which accepted the government of Lithuania, was the Danish government to sign the official record concerning the bilateral cooperation with Lithuania. The Danish side foretold the resumption of diplomatic relations when "if the situation allows". On $8^{\text {th }}$ April 1991 year the People's Town Council signed the act of the cooperation between Vilnius and Cracow. $29^{\text {th }}$ October 1991 year the act "Of National Anthem of Lithuania" came into force. 24 $4^{\text {th }}$ February 1992 year the White Russian Foreign Affairs Minister laid territorial claims to Lithuania, later the government of White Russia contradicted them. $4^{\text {th }}$ June 1995 year decision was taken concerning renewed party schools, they were annulled in 1990 year. $17^{\text {th }}$ November 1995 year a bomb exploded in the editorial office of the daily newspaper "Lietuvos rytas". Lithuanian Annals 1988-2000. Warszawa 2001; Lithuania. $1990 \mathrm{nr} 1$ s. 103-129.

${ }_{21}$ Later blockade of Polish programme took place, its emission was restored since $1^{\text {st }}$ September 1990 year.

22 I Congress of Jewish Culture Society took place in Vilnius on 5 March 1989 year. The Society brought together different Jewish organizations e.g. sport club "Makabi", the youth organization "Tkuna". The president of JCS was Emanuelis Zingeris, philologist and a member of the Seym Council "Sajudis".

23 Lithuanian Annals 1988-2000. s. 56.

24 Painting exhibition „What a Wonderful World", Vilnius evening "In the sphere of Vilnius traditions".

25 Dispute occurred in April 2004 year between Lithuanian Poles and Episcopal Curia in Vilnius, it concerned Jesus Christ Merciful's picture in the church under the invocation of the Holy Ghost in Vilnius.

26 Universitas Studiorum Polona Vilnensis was registered the university a few following years did not receive license.

27 Lithuanian partners of UNC are: Universitas Studiorum Polona Vilnensis, the Vilnius University, the Great Prince Vituas' University in Kaunas. The Institute of the Baltic State Economy functionates in the Warsaw School of Economics in the College of the World Economic.

28 Important outcomes scientists obtained to make researches of rejuvenations of bridże over build in the end of XVI century and in Trakai to make researches of three bridges over built under Great Prince WITOLDA.

29 Historical education and contemporanceousness. The jubilee book dedicated to Professor Adam Bochenski on the occasion of the fortieth anniversary of didactic and scientific work and of seventh birthday, edit by the Opolski University.

$3028^{\text {th }}$ April 1998 year in the University of Vilnius two lectures of Polish scientists - professor Sybilii Bidwell on the theme of neighborhood of Poland and Lithuania from 1410-1898 and professor Longin Pastusiak on the theme of Polish way to the NATO. Abolition of censorship and freedom of statement enabled scientists representation of standpoints of their people in delivered lectures e.g. "University of Vilnius - supranational centre of education of artists 17971939", by professor Stanislav Kalembka, publicated in Vilnius in 2001 year ${ }^{31}$. Professor Alfredas Bumblauskas from the Vilnius University delivered the lecture "Past Vilnius and historical consciousness of nations of the Grand Duchy of Lithuania" in Universitatis Nicolai Copernici in Torun.

32 Czesław Miłosz received the honourable citizenship of Lithuania.

33 Paulius Sangavičius, a lecturer in the Academy of Music in Klajpeda, a director of Faculty of Culture and an international judge of modern dance. 
34 Marcin Woźniak, a student of Warsaw University, has written the scientific work "The Song of New Language" dedicated to creation of M. K. Čiurlionis, estimated by professor Danuta E. Knysz-Tomaszewska.

35 Approved by the Council of Ministers of the Republic of Poland on 26 October 1999, there is no Lithuanian note.

36 The role of libraries in the conditions of EU integration was presented, among others, by A. Ogonowska: Threats and opportunities of Polish libraries after Poland's accession to the European Union - terra incognita and myths (Zagrożenia i szanse bibliotek polskich po wejściu Polski do Unii Europejskiej - terra incognita i mity). Ebib.oss.wroc.pl/2001/25/ogonowska. html.

37 Access2000: Intellectual Property versus The Right to Knowledge?

38 Information Policy and European Union.

39 Knowledge, Information and Democracy in the Open Society: the Role of the Library and Information Sector.

${ }^{40}$ The issues of library science and scientific information in multinational communities were continued at the conference entitled Library and Information in Multicultural Societies, held in Riga in 2004.

41 E.g. organisation of the exhibition in 2004.

42 P.M.Massonius: History of Vilnius University 1781-1832. Toruń 2005.

43 Lithuania. 1990 № 1 p. 163.

44 E.g. S.T. Kondrotas: Collector. Więź 1991 nr 10 p. 119-125.

45 E.g. M. Marinaitis: Triptych I. Tygodnik Powszechny 1991 nr 5 p. 8.

${ }^{46}$ E.g. K. Bradunas: Forest ceremonie. Kresy 1992 nr 11 p. 63.

47 E.g. T. Venclova: Getto. Wiadomości Uniwersyteckie 1991 p. 1.

48 E.g. M. Marinaitis: From Kukutis' Ballads.Literatura 1991 nr 6 p. 10.

49 E.g. Mikutis J: Messy thoughts on the eternal things. Czas Kultury 1991 nr 28 p. 45-55.

${ }_{50}$ E.g. R. Cherniauskas: Gustas joked. Literatura Radziecka $1990 \mathrm{nr} 4$ p. 57-68.

51 E.g. T. Venclova: ABC of Lithuanian literature. Teksty Drugie 1990 nr 3 p. 134-144.

52 E.g. J. Vaitkus: It was a dark night .Znad Wilii $1992 \mathrm{nr} 4$ p. 4.

53 E.g. T. Venclova :Poems embedded in ice. Zeszyty Literackie $1992 \mathrm{nr} 38$ p. 79-81.

54 E.g. A. Sokołowski: Contemporary Lithuanian-Polish literary bonds in Lithuania. Lithuania 1997 nr 3/4 p. 184-189; profiles of creators of Lithuanian culture were discussed: Alicja Rybałko, Eugenijus Ališank, priest Vaclovas Aliulis, Feliksas R. Bajoras, Osvaldas Balakauskas, priest Jonas A. Boruta, Medard Czobot, Viktorija Daujotyte, Leonidas Donskis, Valentinas Sventickas and Markas Zingeris.

55 W. SMoczyŃski: Sullo strumentale plurale in prussiano. Europa Orientalis 1990 v. 9 p. 287 309.

56 E.g. E. Juodalke: Waking up on a sunny...Przeglad Polski-Polish Review, [13. 02], p. 10.

57 E.g. J. Roch: Under Gediminas' posts. Po prostu $1991 \mathrm{nr} 1$ p. 5.

58 E.g. J. Aistis: Podróż. Odra 1990 nr 6 p. 17.

59 E.g. R. Maskoliunas: Fandom litewski. Nowa Fantastyka. 1991 nr 5 p. 68.

${ }^{60}$ Song of Zemaitis of the Telsiai region in the war of 1831. Pieśn Skrzydlata. $1991 \mathrm{nr} 1$ p. 5, [fragments of the poem].

${ }^{61}$ S. Szostakowski: East-Prussia background of the magazine. Studia i Materiaty. $1992 \mathrm{nr} 37 \mathrm{p}$. 9-26.

${ }^{62}$ L. Jaciniavicius :The face. Tytut $1992 \mathrm{nr} 4 \mathrm{p} .103-110$.

63 E.g. T. Venclova: As a Lithuanian with a Pole. Gazeta i Nowoczesność $1990 \mathrm{nr} 27$ p. 1-3.

64 E.g. T.Venclova: Lithuanians and Poles. Akcent 1992 2/3 p. 39-42.

65 E.g. V. Jasukaityte: Poorly visible. Przeglad Kresowy 1991 nr 5/6 p. 41.

${ }^{6}$ E.g. J. Marcinkevichius: Triptych (3. Evening with fire). Kurier Wileński 1992 nr 2 p. 4. 
67 V.Kudrika: Lietuvos himnas. Magazyn Wileński. 1990 nr 6 p. 5.

68 E.g. J.Marcinkevichius: Midnight II. Czerwony Sztandar. $1990 \mathrm{nr} 27$ p. 5.

69 E,g. Cz. Miłosz: Conversation about Lithuania. Wiadomości Uniwersyteckie 1991 nr 5 p. 8.

70 E.g. T.Venclova: Open letter to Lithuanians and Poles in Lithuania. Lithuania $1990 \mathrm{nr} 1 \mathrm{p} .154-$ 165.

71 E.g. B. Tarnowska: In the speech of all elements..." Semantics of catastrophic motives in the poetry of Czesław Miłosz. Litteraria 1992 nr 22 p. 103-126.

72 E.g. B. Tarnowska: In my homeland where I shall not return ...." Evolution of the Lithuanian motive in the poetry of Czesław Miłosz until 1953. Kresy i Pogranicza. Studies and Materials of WSP in Olsztyn $1994 \mathrm{nr} 63$ p. 197-205.

73 Realisation of INTERREG IIIA CBS began in 2005. Cooperation aimed at supporting regional cultural identity, cultural heritage and initiatives of local communities is supported within the framework of this programme.

${ }^{74}$ On the Lithuanian side, the Gediminas Technical University in Vilnius was a co-organiser; its representative was the rector, Professor Edmundas Zavadskas; on the Polish side - Professor Czesław Łepkowski who heads the Institute of Motor Transport.

75 Its chairman, Vaidotas Antanaitis Ph.D., also headed the Lithuanian Nationalists' Association.

${ }^{76}$ Valstybinis Kernaves Archeologijos ir Istorijos Muziejus-Rezervatas.

77 The Polish programme was then blocked and its broadcasting was restored on 1 September 1990.

78 In 1999 Polsat TV channel purchased 51\% shares of Baltic Television.

79 Lithuanian chronicle 1988-2000. Warsaw 2001 p. 282.

80 Address of the editorial office: 2056 Vilnius, Laisves pr. 60.

81 E.g. the programme of Stawomir Sawczuk Lithuanian music in the bluegrass style (Litewska muzyka w stylu bluegrass), i.e. Jonis band, broadcast on 15 April 2005.

82 In 2004 the management of the Polish Television was considering withdrawing from earth broadcasting of the Polonia channel, with this with high costs of broadcasting the programmes. Prompt reaction in Kurier Wilenski (Vilnius Courier) of the Foundation Television for All (Telewizja dla wszystkich), which ten years ago signed the contract for broadcasting of the programmes of Polonia in Lithuania, as well as protests of the Polish society drew the attention of the Senate, the Seym and the Polish government to the issue of maintaining retransmission of the programme. As a result of negotiations which extended over several months, the Polonia Television signed an agreement with the Baltic Television, extending for one year the broadcasting of the programme for Poles.

83 The Foundation Aid to Poles in the East organises competitions for journalists and artists publishing their works in the press published for Poles in the so-called East. In 2005 the Foundation organised a competition for journalists entitled "Polish Pen", a poetic competition "Young Polish poets in the borderland" within the Foundation's programme "Support and integration of Polish creative and artistic environments".

${ }^{84}$ Dziennik Polski na Litwie „Kurier Wileński; address of the editorial office: 2030 Vilnius, Birbyniu g. 4 a.

85 Tygodnik Wileńszczyzny, address of the editorial office: 2600 Vilnius, Rinktines 50, office 501.

${ }^{86}$ Nasza Gazeta, address of the editorial office: 2600 Vilnius, Naugarduko 76.

87 Nasz Czas, address of the editorial office: 2006 Vilnius, Didżioji 40. Magazine addressed to Poles in Lithuania, Latvia and Estonia.

88 Spotkania, address of the editorial office: 2002 Vilnius, Dominikonu 8.

${ }^{89}$ Miesięcznik Polaków na Litwie "Magazyn Wileński”, address of the editorial office: 2056 Vilnius Laisves pr. 60.

${ }_{90}$ Znad Wilii, address of the editorial office: 2001 Vilnius, Isganytojo 2/4.

91 Ateneum Wileńskie, address of the editorial office: 2001 Vilnius, Minties 11-15. 
92 Gazeta Wilenska, address of the editorial office: 2056 Vilnius, Lasves pr. 60. Publication of Vilnius Gazette (Gazeta Wileńska) was suspended in December 2000.

93 Kalendarz Rodziny Wileńskiej, address of the editorial office: 2015 Vilnius, Savanczicy 52-26.

${ }_{44}$ Tygodnik Wileńszczyzny "Przyjaźn", address of the editorial office: 2600 Vilnius, Rinktines 50 , office 501.

95 „Spotkania”, address of the editorial office: 2002 Vilnius, Dominikonu 8.

96 W Kregu Kultury, address of the editorial office: 2056 Vilnius, Ozo 17-57.

97 Wileńskie Rozmaitości.

98 Wiadomości Brukowe.

99 It has a legal status of international organisation and observes principles set forth in the statutes adopted on 3 September 2000. This organisation can be contacted through the Internet at http:// media.wschod.tripod.com.

${ }^{100}$ W. Witter: New magazine in Lithuania. [ 7 October 2005. At the internet site of World of the Polish Community (Świat Polonii)].

${ }^{101}$ Adres internetowy portalu, na którym jest dostępna literature polska - (http://monika.univ.gda. $\mathrm{pl} / \sim$ literat/books.htm)

102 „Kurier Wileński » - http://www.kurierwilenski.lt., „Magazyn Wileński” - http://www.magwil.lt, „Nasza Gazeta” - http://www.tygodnik.lt, „Przyjaźń” - http://www.tygodnik.lt, „Nasza Gazeta” - http://www.nasza-gazeta.tripod.com.

${ }^{103}$ It can be copied from http://www.radio.białystok.pl.

${ }^{104}$ Publications include textbooks, contemporary Lithuanian literature and publications presenting issues concerning the Lithuanian minority in Poland. A magazine addressed to Lithuanians in Poland is available at the following site: http://www.ausra.pl.

${ }^{105}$ A visit of the Polish minister of national education took place on 20-21 February. The following documents were signed then: "Agreement between both ministries with respect to education and university education” („Porozumienie między obu ministerstwami w dziedzinie oświaty i szkolnictwa wyższego"), “Cooperation programme for the year 1992” („Program współpracy na rok 1992") and "Report on establishment of a Commission for examination of issues of history teaching” („Protokół w sprawie utworzenia Komisji do badania problemów nauczania historii”) on 21 February. Seventeen deputies of the National Council protested against the agreement as they considered the agreement to be legally ineffective as it could not be signed by ministers (signing of the agreement was in the competence of prime ministers as it was an international agreement and not an inter-ministry one).

${ }^{106}$ Moreover, the Ministers of National Education of Poland and of Education and Science signed in 1999 an agreement on cooperation of the ministries until 2001.

107 No Lithuanian note.

${ }^{108}$ Legal grounds of activities undertaken for Polish community education and teaching of the Polish language abroad: Act of 7 September 1991 on the system of education, Act of 7 October 1999 on the Polish language, Act of 11 April 2003 on amendment of the Act on the Polish language, Governmental programme of cooperation with the Polish communities and Poles abroad, adopted by the Council of Ministers on 10 December 2002, Ordinance of the Minister of National Education and Sport dated 27 March 2002, Ordinance of the Minister of National Education and Sport dated 15 October 2003, Ordinance of the Minister of National Education and Sport dated 13 October 2004.

${ }^{109}$ Based on the data published by the Ministry of National Education and Sport, concerning 2004.

${ }^{110}$ The university educated students from Ukraine in the framework of scholarship granted by the president of the Republic of Poland in 2001.

${ }_{111}$ There are several facilities in Salčininkai: school, playschool, boarding house and children's home. 
112 Schooling Association, in compliance with the agreement with the Vilnius authorities, co-finances in $49 \%$ renovation of elementary schools and playschools in Vilnius. Basis: Radio From the banks of Neris 103.8 FM, 30 June 2005. In 1997 journalists delivered information from a Polish school in Pabrade that "Polish children often do not have anything to eat”. This information was denied by the headmistress of the facility and her opinion was broadcast by BNS agency.

${ }_{113}$ Lithuanian Chronicle 1988-2000 p. 292.

${ }^{114}$ Tygodnik Wileńszczyzny of 9-15 June 2005 stated than only in the school year of 2004/2005 twenty-two Polish educational facilities lost the status of independent schools as a result of overstated requirements in terms of the number pupils needed to form a class.

$115 \mathrm{http} / / /$ www.tpgiw.prv.pl

116 The Lithuanian minority did not deliver to the authorities of the Sejny district within the required time a list of pupils who would learn at the centre and that is why the Centre of Lithuanian Education did not receive money from the educational subsidy. Funds for the operation of the CLE were delivered by the government of Lithuania. The Association of Lithuanians expresses critical opinions concerning cooperation with the authorities of the Sejny district.

${ }_{117}$ Point 5 of this Act stipulates: All schools of general education must ensure knowledge of the state Lithuanian language according to the norms specified by the Ministry of Education and Science.

${ }^{118}$ Fundamental difference between the Community and international law. T. Biernat: Community of the law. On peculiarities of the European system. Torun 2002 p. 92-94.

${ }^{119}$ W. Czapliński: European Union. Domestic law...(Unia Europejska. Prawo krajowe, wspólnotowe, unijne I międzynarodowe. Pierwszeństwo to nie nadrzędnošć). Rzeczpospolita 2004 nr 209 p. C3; fundamental laws were treated on different grounds than the other norms of the internationat law. They were considered as the principles of law, but they were not part of the enacted law. Although the Communities' establishment treaties in several places refer to the fundamental laws (prohibition of discrimination, free movement of people), their catalogue which could be a guideline for courts applying the Community law has not been formed. W. Czapliński: Outline of the European law (Zarys prawa europejskiego). Warsaw 1999 p. 35.

${ }^{120}$ E.g. Cooperation of partner towns of Poland and Lithuania, drawn up by the Office of the Association of Polish Towns, Polish-Lithuanian Local Government Forum on 31 March - 3 April 1998 Poznań 1998. Lenkijos ir lietuvos miestu-partneriu bendradarbiavimas, Paruošẻ Lenkijos Miestų Sajungos Biuras, Lenkụ - Lietuvių Savivaldybės Forumas 1998 m. kovo mén. 31 d. - balandžio mén 3 d. Poznanè1998 m.

121 The agreement was signed by the authorities of the cities on 18 February 1995, but cooperation between the cities began in July 1973.

122 The level of $29 \%$ was recorded in January 2001.

${ }^{123}$ Based on materials received from the press spokesperson the Elbląg Town Hall.

${ }^{124}$ Detailed information on the Chamber and possibilities to become its member can be obtained from Aušra Publishig House in Puńsk.

${ }^{125}$ Publishing orders are accomplished by, among others, Aušra publishing house.

${ }^{126}$ Lithuanian Centre for Association of Rural Tourism in Kaunas registered office at the Palace of Agriculture of the Republic of Lithuania at K. Donelaicio 2.

${ }^{127}$ Internet site: www.litwatravel.com.

${ }^{128}$ Numbering following the National Edition of the Works of F. Chopin (Wydanie Narodowe Dzieł F. Chopina) (issued by J. Ekier from 1967- 38), 74 № 16 opus numbering of the works published in the year 1855-59 by Julian Fontana, year of creation 1830-31; published in 1857 by A.M. Schlesinger (Julian Fontana), Warsaw $1859 \mathrm{G}$ and W (J. Fontana), number of the piece of music in the edition of All Works (Dzieła Wszystkie) - XVII/16. 


\title{
Współpraca kulturalna między narodami jako ważny czynnik zrównoważonego rozwoju społecznego regionu Europy Środkowowschodniej w Unii Europejskiej
}

\author{
STRESZCZENIE
}

\begin{abstract}
Współpraca kulturalna i społeczna między narodami z Europy Środkowowschodniej kształtowała się przez wiele stuleci. W XX wieku narody tej części Europy zostały poddane próbie ujednolicenia kultur narodowych poprzez wprowadzenie kultury socrealistycznej. Przesłaniem współpracy kulturalnej jest integracja społeczno-kulturowa. Stosunki między Polską i Litwą wypracowane w ciągu ostatnich 15 lat mogą być przykładem rozwoju współpracy pomiędzy innymi krajami Europy na poziomie państwowym i regionalnym, jak również dla obudzenia inicjatywy obywatelskiej. Nawiązywane kontakty mogą stać się zalążkiem współpracy i stosunków dobrosąsiedzkich, a w perspektywie rozwoju społecznego regionu pomiędzy Bałtykiem, Adriatykiem i Morzem Czerwonym.
\end{abstract}

\begin{abstract}
Cultural and social cooperation among nations lived in East and Central Europe has been sprung up over many centuries. In the $20^{\text {th }}$ century, the nations of the part of Europe were subjected to an attempt to standardize their national cultures by means of introducing the socialist realistic culture. At present the message of cultural cooperation is social and cultural integration. Relations between Poland and Lithuania can be an example for development of cooperation among the other countries of Central and Eastern Europe on the state and regional levels, as well as example for educational institutions and economic associations. The connected relations may become germs of cooperation and good-neighbourly relationship as well as in the perspective of social development of the region among the Baltic Sea, the Black Sea and the Adriatic Sea.
\end{abstract}

